\title{
Multiple-Line Identification of Socio-Ecological Stressors Affecting Aquatic Ecosystems in Semi-Arid Countries: Implications for Sustainable Management of Fisheries in Sub-Saharan Africa
}

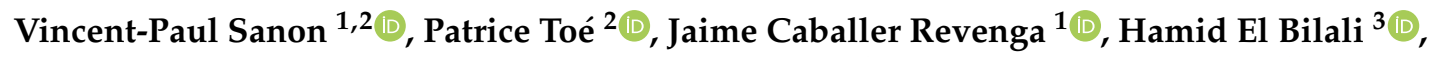 \\ Laura Janine Hundscheid ${ }^{1}$, Michalina Kulakowska ${ }^{4}{ }^{\circ}$, Piotr Magnuszewski ${ }^{4,5}$, \\ Paul Meulenbroek ${ }^{6}$ (D), Julie Paillaugue ${ }^{1}$, Jan Sendzimir ${ }^{1,6}$, Gabriele Slezak ${ }^{7}$, Stefan Vogel $^{8}$ \\ and Andreas H. Melcher ${ }^{1, * D}$ \\ 1 Institute for Development Research, BOKU-University of Natural Resources and Life Sciences, \\ Peter-Jordan-Strasse 76/I, 1190 Vienna, Austria; vincent.sanon@boku.ac.at (V.-P.S.); \\ jacabenga@gmail.com (J.C.R.); laura.hundscheid@boku.ac.at (L.J.H.); j.paillaugue@lilo.org (J.P.); \\ jan.sendzimir@boku.ac.at (J.S.) \\ 2 Institute for Rural Development, University Nazi BONI, Bobo-Dioulasso 01 BP 1091 Bobo 01, Burkina Faso; \\ patrice_toe57@yahoo.fr \\ 3 International Centre for Advanced Mediterranean Agronomic Studies, via Ceglie 9, \\ 70010 Valenzano (Bari), Italy; elbilali@iamb.it \\ 4 Centre for Systems Solutions, Stefana Jaracza 80b/10, 50-305 Wrocław, Poland; \\ michalina.kulakowska@crs.org.pl (M.K.); piotr.magnuszewski@crs.org.pl (P.M.) \\ 5 International Institute for Applied Systems Analysis, Schlossplatz 1, A-2361 Laxenburg, Austria \\ 6 Institute of Hydrobiology and Aquatic Ecosystem Management, \\ BOKU-University of Natural Resources and Life Sciences, Gregor-Mendel-Strasse 33, \\ 1180 Vienna, Austria; paul.meulenbroek@boku.ac.at \\ 7 Institute for African Studies, University of Vienna, Spitalgasse 2, 1090 Vienna, Austria; \\ gabriele.slezak@univie.ac.at \\ 8 Institute for Sustainable Economic Development, BOKU—University of Natural Resources and Life Sciences, \\ Feistmantelstraße 4, 1180 Vienna, Austria; stefan.vogel@boku.ac.at \\ * Correspondence: andreas.melcher@boku.ac.at; Tel.: +43-01-47654-93411
}

Received: 30 March 2020; Accepted: 19 May 2020; Published: 26 May 2020

\begin{abstract}
Water resources are among the fundamental resources that are the most threatened worldwide by various pressures. This study applied the Driver-Pressure-State-Impact-Response (DPSIR) framework as an innovative tool to better understand the dynamic interlinkages between the different sources of multiple stressors on aquatic ecosystems in Burkina Faso. The triangulation of evidences from interviews, literature reviews, and strategic simulations shows that several human impacts as well as climate change and its effects (such as the decrease of the water level, and the increase of the surface water temperature) are detrimental to fish productivity, abundance, and average size. Furthermore, the ongoing demographic and nutritional transition is driving cumulative pressures on water and fish resources. In this context, the development of aquaculture could offer alternative livelihoods and help fish stocks in natural ecosystems to recover, thereby reducing fishermen's vulnerability and easing overfishing pressures. Further, the empowerment of the actors and their participation to reinforce fisheries regulation are required to escape the current "regeneration trap" and to achieve a sustainable management of aquatic ecosystems in Burkina Faso.
\end{abstract}

Keywords: fisheries management; multiple stressors; stressors interaction; anthropogenic pressures; climate change; DPSIR; strategic simulations; interviews; river systems; Burkina Faso 


\section{Introduction}

Although a tiny fraction, $0.01 \%$, of the world's water and about $0.8 \%$ of Earth's surface, fresh water supports $6 \%$ of all species (100,000 out of 1.8 million) described for aquatic or terrestrial ecosystems [1]. This makes both inland water and its biodiversity an essential resource [1,2] for the economy, landscape, science, and education [1]. However, this extremely valuable resource is increasingly threatened on the planet because of global change [1-5], the human global footprint, and the number of humans, with their concomitant demand for this resource for food, health, and clean water [6-9]. Worldwide, rivers are among the most threatened ecosystems; multiple human pressures, such as pollution, water abstraction, river channelization, damming $[10,11]$, and their complex interference with natural processes, are key to understanding the continuous degradation of such water resources [11].

As far as fisheries are concerned, global estimates reveal an increasing overexploitation; fish landings from inland waters have increased $400 \%$ since 1950, and many freshwater stocks are at risk of collapse [7,12]. In 2016, excluding aquaculture (aqc) production, Africa's inland capture production reached nearly 2.9 million tons, accounting for $25 \%$ of the global catches, and ranking the continent second worldwide after Asia (7.7 million tons produced) [13].

The issues related to water and fish have a special resonance for Burkina Faso (BF), a West African country located in the Sahel, a region which stretches from Senegal eastward to Sudan [14]. BF is a landlocked country bordered by six countries viz. Mali in the North and West, Niger in the East, and Ivory Coast, Ghana, Togo, and Benin in the South. The Burkinabe population exceeded 19 million inhabitants in 2017 with an average annual growth rate of 3.1\% [15,16]. The population is highly reliant on agriculture as a means for subsistence but also as a source of income [17]. Indeed, the gross domestic product (GDP) is mainly based on the primary sector, including agriculture, livestock, forestry, and fisheries [18]. In 2018, the GDP per capita reached 715.12 USD [19]. In 2017, BF ranked 183rd out of 189 countries. Its very low human development index of 0.423 [20] is the expression of a widespread poverty that increases the vulnerability of the populations to climate change impacts, especially in rural areas, as more than $80 \%$ of the population live directly on subsistence agriculture [20,21].

With two-thirds of the country's climate being arid to semi-arid and only a few perennial waterbodies that persist throughout the year [22], the construction of permanent or temporary reservoirs has been perceived as a promising way to develop water resources to address water scarcity and improving food security in BF, notably in highly populated areas (e.g., around the Nakambe river) [22,23]. In 2018, nearly 1700 reservoirs were identified and listed [24,25], ranking BF as the country with the highest density of reservoirs in West Africa [26]. About $90 \%$ of these reservoirs do not exceed a storage capacity of $1 \mathrm{Mm}^{3}$ (million cubic meters) and are referred to as "small reservoirs" [27,28]. The water sources, especially groundwater and reservoirs, depend on rainfall [29]. Moreover, in a time of global climate warming, the integrity of these water sources is threatened by rising trends of increasing ambient air temperatures, which cause water loss due to evaporation, especially in the Sahelian zone [4].

Very few recent studies have been carried out on fish assemblages in BF $[11,28,30,31]$, and the resulting lack of knowledge hinders efficient conservation measures and conceals the economic and ecological roles of fish [32]. The knowledge gap regarding multiple stressors in the freshwater ecosystem is a critical hindrance to efforts to establish sustainable inland fisheries. The interactions and cumulative effect of multiple stressors have been scarcely studied [2,7], while much research has been carried out about the individual effects of five key pressures on the freshwater ecosystem, including water extraction, habitat degradation (fragmentation and chemical pollution), over-exploitation, invasive species, and climate change $[7,8,12,28,33]$. Considering the increasing threat water resources and aquatic ecosystems are subject to, there is an urgent need for research [2] to fill knowledge gaps in freshwater ecosystems [2,3,34-36], especially in semi-arid and resource-poor countries, such as BF.

The overall goal of this paper was to understand the effects of the combination of multiple socio-ecological stressors on the integrity and performance of aquatic ecosystems in BF, i.e., the main tributary to the Volta river system, the Nakambe River or White Volta, and to analyze ways to improve 
the management of fisheries in the context of climate change. Furthermore, we explore how fish farming increases our capacity to address the twin challenges of aquatic ecosystems' degradation and food insecurity in BF.

\section{Methods}

\subsection{Overarching Approach}

A qualitative approach was applied to identify and explore new findings and to flexibly adapt how research was conducted along multiple parallel pathways [37]. Fishers and aquaculture (aqc) farmers as well as decision makers and staff members of state services at local, provincial, and national levels were involved in the study as informants but also, from a participatory perspective, as contributors to our common goal of defining future pathways toward a sustainable management of aquatic ecosystems.

We developed, assembled, and used multiple lines of evidence [38] across the Drivers-Pressure-State-Impact-Response (DPSIR) framework. Qualitative data from literature reviews, interviews, and strategic simulations were combined (Figure 1).
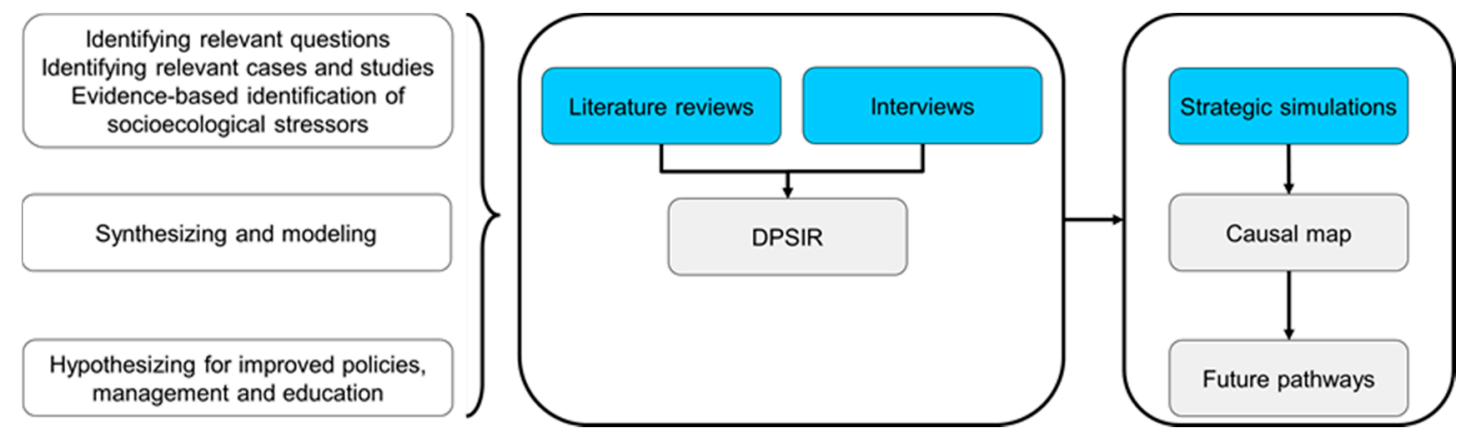

Figure 1. Multiple lines of evidence. This figure describes our approach of multiple lines identification of socio-ecological stressors in Burkina Faso's aquatic ecosystem. The Drivers-Pressure-State-Impact-Response (DPSIR) serves as the analytical framework shaping this research. The different research steps are displayed on the left side. The different methods or lines of evidence are highlighted in blue and the outcomes in grey. Literature reviews and interviews were used to elaborate a DPSIR model. This contributed as a background to the strategic simulations that yielded a causal map, and future pathways toward sustainable aquatic ecosystems and fisheries.

\subsection{Literature Reviews}

The aim of the literature reviews was to take stock of previous studies and gather evidence related, on the one hand, to the causal relations (drivers, pressure, state, impact, and responses) in BF water bodies and fisheries and the development of aqc, and, on the other hand, to identify the main adverse effects of climatic variabilities (climate change) on water and fish resources. Further, it helped in preparing relevant research questions and an interview guide.

A systematic review of published articles and grey literature was conducted using the Title-Abs-Key strings: ("Burkina Faso" OR "Niger" OR “Mali" OR "Benin" OR “Togo" OR "Ivory Coast" OR "Ghana" OR "West* Africa" OR "Sahel") AND ("climat* chang*" OR "global change" OR "global warming") AND (fish AND NOT marine); aquaculture AND ("Burkina Faso" OR "West Africa”). The search was carried out on Scopus for scholarly peer-reviewed literature and various databases for articles published in journals that are not indexed in Scopus as well as grey literature, such as Google Scholar@ and Google (C). A "snowball search" was used to include articles from reference lists of relevant publications and articles based on known literature and recommendations from colleagues. The same strategy was applied to search for literature in the French language, including published or grey literature. Once references in articles were observed to be particularly redundant, the snowball and grey literature searches were stopped. 
The papers chosen to be reviewed focused on abiotic or biotic factors related to fish resources and the environment, and to the pressures arising from climate change impacts. This included the effects of anticipated climate variability on hydrological regimes in the region, and the resulting observed responses of fish. In addition, this included papers focusing on fishing communities' reaction to adapt to such changes and to reach sustainable practices. Papers regarding West Africa were excluded if (i) they dealt with coastal fish biodiversity and estuarine ecosystems (since BF is a landlocked country), and (ii) the climate of the study area diverged too much from Burkina Faso's climate. The exceptions were papers considering the need for research to better comprehend the evolution of climate change impacts in the region. The search yielded 190 documents (134 articles and 56 grey literature publications). Out of these, 65 articles were included ( 39 articles and 26 grey literature documents). Data and analysis from this literature search identified the components of the DPSIR and the abiotic and/or biotic variables recognized as being affected by climate change to complete the DPSIR causal map. The abiotic variables here referred to various climatic factors (e.g., precipitation variability, air temperature) and to physical and chemical characteristics of waterbodies (e.g., water temperature, dissolved oxygen content).

\subsection{Interviews}

We performed 27 interviews. Eighteen expert interviews focused on (i) pressures on reservoirs and streams, (ii) the current state of aqc, (iii) the potential for and impacts of aqc, (iv) the constraints for aqc development, and (v) the first steps to support the development of aqc. Meanwhile, nine complementary interviews with experts and stakeholders addressed interviewees' knowledge about climate-driven factors and the source(s) of their information, impacts on fish, policy recommendations, and sources of information regarding climate change.

The 18 expert interviews took place in BF from January to February 2018. Key persons from BF whose field of expertise is strongly related to fisheries and aqc were selected during a meeting with the team of the Austrian SUSFISH-Plus project (Sustainable Management of Water and Fish Resources in Burkina Faso) [39-41] as experts for the interviews. Other interviewees were selected based on the "snowball principle" [42], i.e., they were recommended by previous interviewees or key informants. Among the interviewees, eight were directors or employees at the national and regional level in departments related to fisheries and aqc. Six were academics: Professors, post-docs, PhD, and master's students from the University of Ouagadougou and the University of Nazi BONI in Bobo-Dioulasso, with backgrounds in natural or sociological sciences, both related to the topic of fisheries. Some ministerial and institutional officials were SUSFISH-Plus team members too. Four interviewees were aqc operators. Nine of those experts were SUSFISH-Plus team members from BF.

As far as the nine complementary interviews with experts and stakeholders are concerned, they were performed during the strategic simulations in Ouagadougou (see Section 2.4.) with aqc and fisheries' stakeholders and experts, including the president of the Fishermen Association and the president of the Women Processing Fish Association in Koubri (about $30 \mathrm{~km}$ South from Ouagadougou), the traditional canton chief of Koubri, the secretary-general of the Sport Fishermen Association in Ouagadougou, a professor, a research engineer, a member of the General Directorate of Fish Resources, a member of the Ministry of agriculture and hydro-agricultural development, and the program head of the International Union for Conservation of Nature (IUCN)-Burkina Faso. Six of the interviewees are working on a country-wide scale, and three are working in Koubri.

The results of the systematic literature reviews were qualitatively summarized and triangulated with the outcomes of the interviews (Figure 1) to cross-check and, where possible, enrich the results, one from another, and to thereby identify and describe the various components of the DPSIR framework: The potential drivers, pressures, current state of waterbodies, impacts, and responses. Regarding the construction of the DPSIR, the changes described in both the literature and interviews, or highlighted as being of special concern in one of these sources, were considered as relevant and are shown in the DPSIR causal map. 


\subsection{Reference Analytical Framework: DPSIR}

The DPSIR framework was originally elaborated by the European Environment Agency (EEA) in 1999. It is a comprehensive systems-thinking framework that encompasses cause-effect relationships between interacting components of social, economic, and environmental systems [43]. It helps to simplify complex reality, to promote communication in an illustrative way, and thus assists to close the gap between science and decision-making [44]. The DPSIR has barely been used in Africa, thus it is an innovative tool for policy recommendation that can be of great interest for African governance $[44,45]$. The DPSIR has proven to be effective in organizing and communicating complex environmental information for policy formulation; therefore, it has been adopted as an analytical framework for environmental assessment $[45,46]$ to examine land cover change [45], to identify major fisheries problems, adopt standardized indicators, and improve fisheries management [44,47-50]. The implementations of the DPSIR are variable. For instance, in Africa, Agyemang et al. [45] used two complementary assessment techniques: Geographical Information Systems (GIS) and remote sensing to assess the state of the environment (land cover change from 1990-2004) and participatory research methods (interviews, focus group discussions, participants' observations) to collect and triangulate participants' views in order to review the results of the first phase (cf. GIS and remote sensing), verify the results obtained, discuss the driving forces, pressures, and impacts of the changes, and reflect on their future responses. Instead, Gebremedhin et al. [44] describe the drivers, pressures, state, and impact based on the literature whilst responses were based on the literature, personal experience, and informal communication with fishermen, experts, and scientists [44]. In the European context, Knudsen et al. [48] also applied a modified DPSIR model, emphasizing drivers-pressure-state (DPS), to identify drivers for fishing pressure on the basis of ethnographic fieldwork and interviews in the coastal areas, Samsun fisheries on the Turkish Black Sea coast.

In the current research, the DPSIR was used as a tool to process the data from the literature and interviews, to elaborate the DPSIR model, and then to structure the presentation of the results. The factors stressed in both the literature and interviews or highlighted as being of special concern in one of the data sources are shown in the model diagram. The same method was used to identify all components of DPSIR.

The components of the DPSIR were defined as follows based on the guidance document for the analysis of pressures and impacts in the framework of the Common Implementation Strategy for the Water Framework Directive [51] and Chu [7]:

- Drivers are agents or processes that dominate the system's dynamics in such a way that they are unavoidable factors of change to ecosystems or human activities, including social, demographic, and economic development. As such, they profoundly influence nature and society.

- Pressures are direct results of the drivers. They can be human actions in response to the driver that affect aquatic ecosystems or the effects of the driver in the case of natural drivers (e.g., change in water chemistry due to the application of pesticides).

- State consists of quantitative or qualitative indicators that describe a component of the ecosystem of interest. In this study, it refers to the condition of water body (i.e., physical, chemical, and biological characteristics) resulting from both natural and anthropogenic factors.

- Impacts correspond to the effects of changes of the state on the ecosystem components, such as fish kill and human well-being, including economic prosperity, safety, and cultural well-being.

- Responses are the measures taken to improve the state of water bodies and to ensure the provision of ecosystem services. They can be also policies to prevent, mitigate, or adapt to the impacts triggered by the alterations of environmental states.

\subsection{Strategic Simulations}

The strategic simulations focused on the Nakambe (White Volta), one of the main river basins of $\mathrm{BF}$, where the country and its residents face important development and environmental challenges. 
The implementation of the simulations involved two steps in defining issues and their relations; (i) the current situation, and (ii) the future pathways; both are further described in this section. Prior to these steps, a list of important factors in the context of the basin and fish harvest were prepared based on an in-depth literature search, including the abovementioned methods (see Sections 2.2 and 2.3.) (Figure 1). Then, a systems diagram or "causal map" was created to represent the dependencies between the various factors.

Strategic simulations, known also as policy simulations or policy exercises, is an interactive participatory tool to engage stakeholders, researchers, and policy makers in the development of strategic insight. The participants of policy simulations work with real-world data and issues that resemble or are exact to their experience [52]. In the strategic simulations approach, participants explore real policy issues, using design elements known from serious games, such as game boards or cards, to structure communication [53] as well as to include feedback that participants receive based on their decisions. According to Solinska et al. [54], this "spurs the dynamics of the face-to-face simulations and adds the sense of realism, urgency and fun". As a result, even stakeholders without relevant academic backgrounds are able to engage in highly complex situations [55].

The stakeholders participating in the strategic simulations explore possible "pathways" embedded in existing external scenarios [56]. Past evaluations of similar processes indicate that the approach can be quite efficient in the development of strategic decisions [57]. It prepares stakeholders for a wide array of outcomes while considering existing strategies and plans rooted in real data and participants' own experiences. Strategic simulations have been successfully implemented to support stakeholder engagement and the data analysis process in various areas of research and strategy development, for example, flood risk on the Thames river [58], extreme sea-level rise due to climate change [59], social aspects of river-floodplain management [60], and international management of global climate change [61], but to the authors' knowledge, SUSFISH-Plus presented the first instance of such tool being used in a context of aquatic ecosystems in BF.

The strategic simulations (SSs) provided an opportunity for stakeholders to meet and define the issues related to sustainable fisheries using a map of BF as a visual representation of the spatial distribution of major resources and problem areas in aquatic socio-ecosystems. This exercise simulates a science-policy dialogue over a few hours that in real life might have taken months to years. As such, this exercise enhances learning by compressing space and time to speed learning and helps stakeholders to co-develop a better mutual cognitive understanding and a deeper discussion of key issues to develop recommendations relevant both to science and policy.

The SS exercise was implemented during two workshops. The first workshop took place in Vienna in September 2018 and aimed at identifying the important challenges and opportunities within a discussion that included an expanded scope of indicators during the exercise with the SUSFISH-Plus team. The second workshop took place in Ouagadougou in February 2019. It convened 42 stakeholders from $\mathrm{BF}$ to jointly discuss desirable futures and pathways with regard to fish management and water security. Twelve of the participants were fishery stakeholders and decision-makers regarding water and fisheries, including fishermen, fish sellers, fish farmers, the representative of rural municipality, representatives of the General Directorate of Fish (Ministry of Animal and Fish Resources), and the General Directorate of Agriculture and Hydraulic (Ministry of agriculture and hydro-agricultural development), a traditional chief. Other 12 participants were students. Additionally, SUSFISH-Plus members participated as facilitators (6 persons), scientific committee providing expert assistance to the participants ( 3 persons), and observers to record the key information of the simulations ( 9 persons).

\subsubsection{Current Situation}

This step consisted in reviewing the current situation in the Nakambe Basin and its major challenges in the context of fisheries. The process consisted in representing a simplified visual format of the Basin (Figure A1). Thus, a predefined set of materials, including Nakambe basin maps and cards representing the "entities" (i.e., land use, natural entities, fish, water, energy, transportation, 
safety, waste management, telecommunication, society-related facilities, and infrastructure), "processes (activities)" (i.e., natural process, social/technological activities), and "indicators" (e.g., food production) were provided to facilitate discussions. The materials, including thematic areas, were chosen to provide sufficient information without excessively narrowing the participants' scope of exploration and breadth of choices. Subsequently, participants were asked to define smaller areas within the basin that could be characterized by a different set of cards. Each area was assigned one of the four "land use categories" (viz. environment and agriculture, fish, industry, and risk zones/hot spot). Participants were free to move the cards around the map and add or remove them to depict the situation according to their expertise and to add new factors (i.e., economy, society, environment, water, food, energy, and fish) that were not included in the simulations.

After describing the current situation, including the challenges, risks, and opportunities on the spatial representation of the basin, the participants moved to the next step, the so-called "causal map". The causal map presented causal relations between indicators. All key indicators and correlations between them were identified by participants in the Vienna workshop. During the workshop in Burkina Faso, participants assessed the level of each indicator and moving through the causal loop, translated the level of indicator into its impact on next one. Stakeholders were encouraged to propose changes to the causal loop; however, no suggestions were made by the participants. The initial rating on a scale from 1-5 (with 1 being the lowest, 3 neutral, and 5 the highest value) was recoded as follows: Low (1-2), medium (3), and high (4-5). The interpretation of the levels depended on the indicator. Indeed, the 5 th level of pollution can be interpreted as being very negative, whereas the same level of education can be seen as a very positive achievement.

\subsubsection{Future Pathways}

The future pathways exercise was designed to develop visions for the Nakambe basin and beyond as well as pathways leading to such visions. Three different groups worked on three different focuses, viz. (i) water and environment, (ii) food and fish, and (iii) economy and energy, respectively, to develop three visions together with their corresponding pathways, starting from clear ambitious but realistic visions of what can be achieved. To reach desired and holistic visions, the focus priorities were not supposed to eliminate other important concerns. Therefore, the same cards, as in the description of the current situation, were used. The pathways were represented also on the "Causal Map" to allow participants to compare various scenarios and their outcomes. This means they could add new entities or remove previous ones from the map (Figure A2). They could also assume whether these elements represent opportunities or risks, and whether they improve or worsen the current situation.

\section{Results}

\subsection{DPSIR: Identification and Characterization of Socio-Ecological Stressors}

In this sub-section, we present the main drivers, pressures, state, impacts, and responses identified based on two evidence lines, viz. literature reviews and the interviews. The components of the model are graphically represented in the following DPSIR causal map (Figure 2) and a brief description of each component is provided hereafter. 


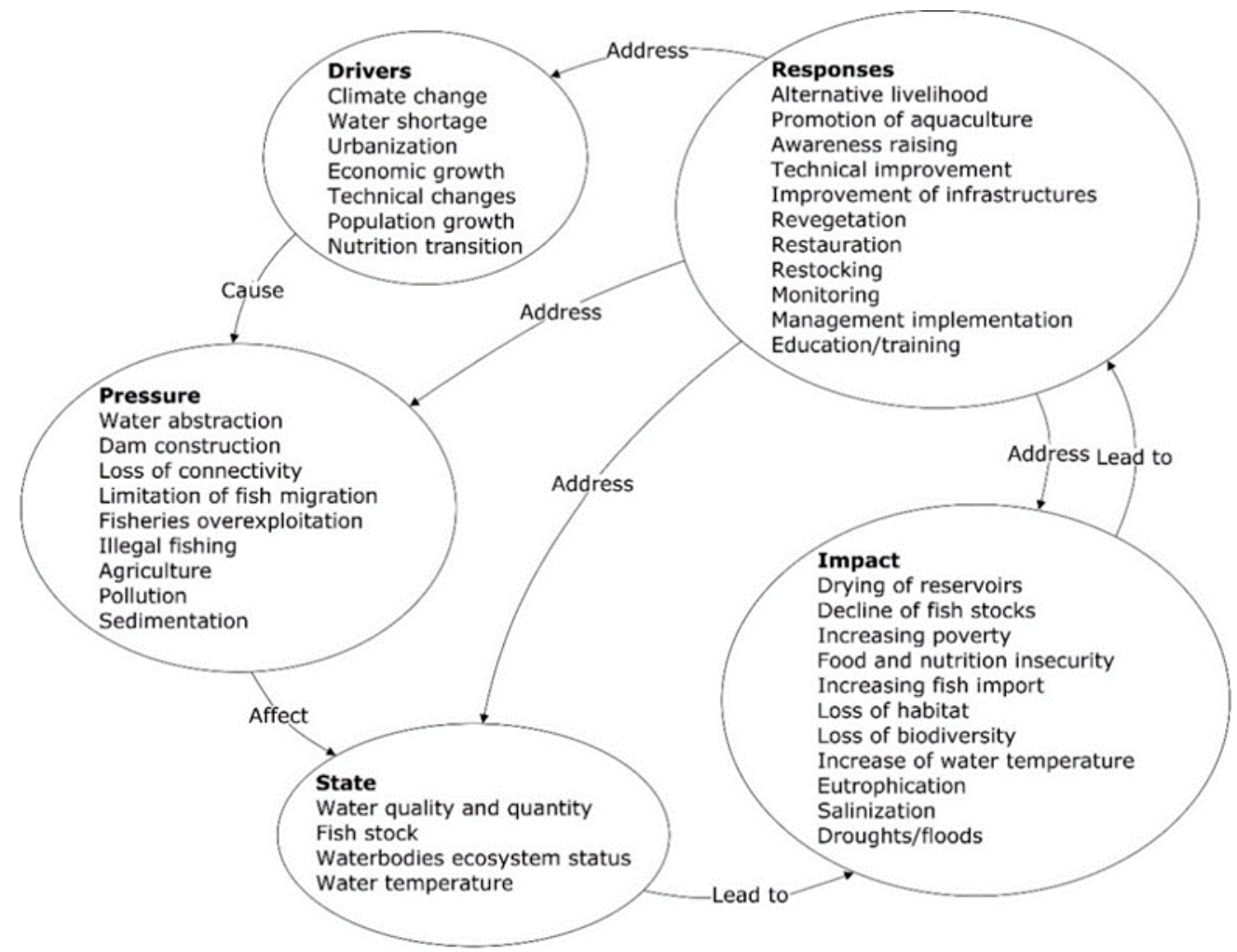

Figure 2. DPSIR relating to the BF aquatic ecosystem. The figure is a simplified representation of key factors in the interaction rather than the entire system. It is based on results from literature reviews and interviews. Source: Modified after Hundscheid [62].

\subsubsection{Main Drivers}

The drivers are essentially based on the literature as the interviews provided little material. Two types of transition occurred during the last century: Demographic and nutritional. Over these transitions, the current drivers of the multiple pressures on water and fish resources in BF have driven the overexploitation of water resources. Regarding the demographic transition, urbanization, technological changes in food processing, as well as economic growth led to the first demographic transition $[63,64]$, which implies a significant increase in the population growth rate. In the current demographic transition stage, the rapid increasing population growth stems from decisive factors, such as an improved food and nutritional supply, better medical care, and a resulting reduced death rate, especially for children under the age of five, while the fertility rate remains constant [65]. Fertility levels in BF have declined only slightly over the past 50 years [66], thus the population has grown by $400 \%$ in the last 50 years. This transition has led to the increase in food and water demand, consequently, and a general overexploitation of natural resources in BF [67].

As far as the nutritional transition is concerned, it shifted the dietary patterns to a less carbohydrate-rich and more protein-rich nutrition $[66,68]$. The demand for fish as a protein source continues to rise because of the awareness of health benefits and lower costs, relative to meat, of fish [69].

Regarding environmental drivers, chronic and widespread water shortage is common to Sahelian countries [30]. Additionally, climate change exacerbates this issue through the decrease of rainfall, changes in the rain distribution patterns and surface flow rates, higher evapotranspiration driven by higher mean temperatures, and disturbance in the soil water balance, etc., resulting in silting of water bodies $[25,62,70,71]$. National experts expect average temperatures to rise by $0.8 \%$ by 2025 and by $1.7 \%$ by 2050 . Meanwhile, the average annual rainfall is likely to decline by $3.4 \%$ by 2025 and by $7.3 \%$ by $2050[62,70]$. 
Human activities, including intensive agriculture, overgrazing, and uncontrolled clearing of land, also contribute to land erosion and worsen climate change impacts [67]. Above all, the overuse of water resources is a core driver of water shortage. The World Meteorological Organization revealed that the total annual demand of water in BF exceeds the available water resources by $10-22 \%$ and should continue to rise due to population growth [72].

\subsubsection{Pressures}

The four principal pressures consist of impacts of climate change (e.g., a decrease in the total annual precipitation, increase of mean annual air temperatures), dam construction, overfishing, and agriculture-related pressures. Regarding the impacts of climate change, both the literature survey and the interviews show that the abiotic indicators exhibiting the most variation due to climate change in the region include the significant decrease in total annual precipitation, the increase of mean annual air temperatures, and an increase in the inter-annual variation in precipitation [73-76]. The literature correlates well on this point with the observations made by different interviewees, such as fishermen, women fish processors in Koubri, a member of the General Directorate of Fish Resources, and the Traditional Canton Chief of Koubri. The intensification of evaporation, triggered by the increase in air temperatures, was often reported, as was the increase of drought frequency. The literature reviews as well as interviews show that abiotic indicators, such as water levels (i.e., volume of surface water available in aquatic ecosystems) is decreasing, as a result of climate change, and impact, in turn, fish (cf. biotic indicators) [74,77]. The major biotic indicators of indirect impacts on fish by climate change were decreases of fish abundance, fish productivity, primary production, and fish average size, and increases in the species extinction rate.

As shown in Table 1, a number of stressors associated with climate change (e.g., a decrease in flooding on floodplains (area and duration), decrease in water level and availability, decrease in dissolved oxygen content, and increase in surface water temperature individually) inhibit fish growth and, thereby, lead to a decrease in the average fish size and fish abundance. The decrease in the water level and availability and the increase of salinity results in a decrease in fish primary production as well as fish productivity. Secondly, both pollution and physical habitat modification (e.g., loss of connectivity, loss of habitats, habitat fragmentation) associated with dam construction affect the decrease in fish reproduction capacity while loss of connectivity blocks fish migration. Thirdly, a number of governance issues, e.g., lack of management implementation, illegal fishing, and ignorance of regulation, lead to decreases in the fish population, in fish biodiversity, and in fish average size. Finally, eutrophication, and a decrease in water quality and quantity, resulting from water abstraction for agriculture, cause a decrease in the fish population. 
Table 1. Pressures, stressors, and their direct effects on the water ecosystem and fishes. The table was elaborated based on the results of the literature reviews realized from April 2017 to March 2018.

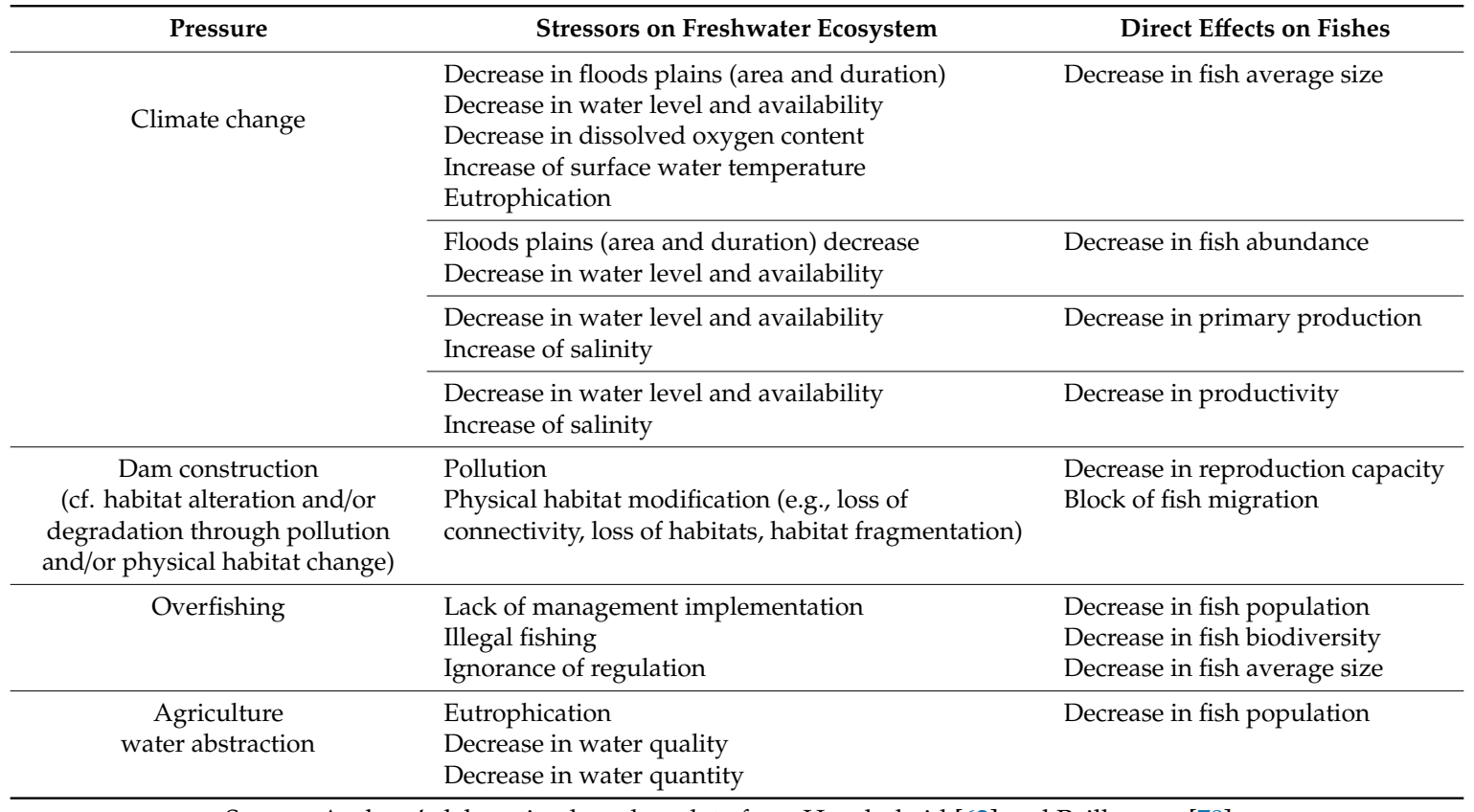

Source: Authors' elaboration based on data from Hundscheid [62] and Paillaugue [78].

\subsubsection{State}

The main indicators of the current state of BF's water bodies consist of the waterbodies' ecosystem status, water quantity and quality, water temperature, and fish stocks. The ecosystem status of waterbodies declines as dam constructions lead to geomorphological changes to aquatic habitats, including the loss and fragmentation of habitats that serve as spawning grounds or habitats for juvenile fish stages of some species [79]. Consequently, species composition shifts such that both species richness [28] and fish stocks [44] decrease.

Similar changes to fish stocks result from the physiological stress caused by decreases of water quality and water quantity [79]. Decreasing water volume accelerates rising trends of water temperature and, hence, the deterioration of water quality. Water quality pressures occur especially in urban areas and agricultural areas [80]. Indeed, pollution through waste dumping in urban areas, pesticides and fertilizer input through agriculture, as well as eutrophication are detrimental to water quality.

The increase in plant and algae growth due to increasing water temperature and the entry of invasive fast-spreading plant species can lead to further eutrophication, oxygen reduction, and thus to impaired water quality. In addition, increasing water temperature can stimulate the growth of harmful algae blooms, which released toxins and may kill fish or trigger fish diseases [69]. An interviewee reported an additional effect of a "new bad aquatic grass" that was spreading very fast in the reservoir of Moussodougou with potential impacts on water quality and fishing activities.

Finally, overfishing is one of the main pressures leading to a decline in the total fish population, fish biodiversity, and average fish size. The latter is directly related to a reduction of the reproductive capacity [81], and thus resulted in a sharp decline of fish catches in the last years [70]. As a result, it is estimated that $56 \%$ of BF's fish species are currently threatened by the effects of human pressures $[70,81]$.

\subsubsection{Impact}

The gap between rising evapotranspiration and decreasing rainfall creates a negative water balance that results in declining water levels [22]. This trend is exacerbated by rising rates of water abstraction. Farmers reported that during the dry season, some reservoirs no longer contain enough 
water to enable crop production [67], a trend that is corroborated by literature projecting that some reservoirs will likely dry out within the next decade [4].

Declines in the status waterbodies reflect critical losses of habitat that cause biodiversity losses and declines in fish stocks. Reduced fish stocks and the reduction of fish size have already led to a sharp reduction of quantity and quality of fish catches in many areas of BF [4,70]. Interviewees, from different administrative levels and sectors, national and regional institutions, as well as universities and fishermen, reported the continuous decline of fish stocks in reservoirs, lakes, and rivers. Additionally, the interviewees argue that declining fish stocks and reduced catches are triggering the increased usage of illegal fishing gears. Since fishing is perceived as "a fight against poverty", illegal fishing will continuously increase, failing any alternative policies to compensate for the loss of income and food or enhanced monitoring, policing, and enforcement.

The changes due to population growth and climate change are likely to have cascading impacts in BF. Socioeconomic impacts include increases in poverty and food and nutrition insecurity. These impacts are exacerbated by the expanding gap between rising population growth and fish demand and declining catches of indigenous fish. The latter leads to the last impact: Increasing fish imports. As a consequence, $\mathrm{BF}$ is highly dependent on fish imports. About $80 \%$ of the fish consumed in BF is imported [13], mainly from China, Taiwan, and neighboring countries like Ghana, Mali, and Ivory Coast.

\subsubsection{Responses}

Responses, i.e., actions intending to prevent, reduce, or adapt to pressures or environmental damage to improve BF's aquatic ecosystems (see Section 2.4.), include, first of all, education and training to raise the awareness and skill sets among resources' users. In particular, women's education can create new perspectives and independency, which, in combination with family planning can, in turn, lead to reduced birth rates $[44,65,81]$ and induce the second demographic transition phase [68].

The implementation of international and national strategies for a sustainable fisheries management and aqc development is mandatory to meet the rising demand for protein and increase domestic fish production. Indeed, these strategies integrate international institutions and regulations, such as the Code of Conduct for Responsible Fisheries (CCRF), considered as a relevant guiding framework for implementing the principles of sustainable development in fisheries and aquaculture $[13,82,83]$. This will, in turn, reduce import dependency and boost the national economy. However, considering the overall lack of good fisheries management on regional and local levels [84], attention should rather be paid to improve the agency of fish managers through policy revision and improved implementation measures at sub-national levels rather than to the formulation of new national policies.

This lack of implementation can be traced back to the government's low deployment of resources for the fisheries sector at regional and local levels. Indeed, interviewees described the sector as "neglected". Our evidence, from interviews and literature, recommended that reversing this trend requires improved communication of the value of the sector to decision makers and implementation of multi-level governance that effectively functions at local and regional levels. In addition, improved collection of reference data would permit the long-term evaluation of policy performance [84]. Further, the collaboration of national institutions on different levels and international organizations is proposed as a way to develop and implement strategies for addressing climate change challenges.

Technical solutions to improve the sustainability of fisheries include the improvement of infrastructure and of the quantity and quality of critical habitats. A campaign to construct and validate fish ladders by management strategies could improve fish migration, which historically was much higher when most water bodies were rivers [11]. This improvement of connectivity is likely to raise fish diversity and abundance. Additionally, the revegetation and restoration of riparian buffer forests along the water bodies are suggested to improve water quality in agricultural areas and mitigate the siltation of reservoirs $[4,80]$. Furthermore, restrictions on fertilizer and pesticide usage should be introduced, and development towards more organic farming should be pursued. 
Finally, to prevent further increases in poverty and malnutrition, experts recommended the development of alternative livelihoods to compensate for declines in incomes and food supplies due to declines in local fish catches. In this respect, both the literature and interviews confirm a high potential for aqc to provide alternative livelihoods that contribute to the recovery of fish stocks in reservoirs and to improve food security and livelihoods.

\subsection{Strategic Simulations}

The identification of socio-ecological stressors was done using another line of evidence, viz. strategic simulations. This exercise permitted participants (SUSFISH partners and fishery and aqc experts and stakeholders) to share their views of important stressors through an interactive tool. The results described the summary of stakeholders' work during the workshops.

\subsubsection{Causal Mapping of the Current Situation}

The key causal factors and their relations that influence the sustainability of fisheries in BF, which were revealed through the strategic simulations exercise, are mapped in Figure 3. This map shows that most of the indicators relating to wellbeing (including health security, food security, gender equality, and income) have a low level while high economic inequalities prevail. Further, stakeholder responses during the exercise reflected how wellbeing and development can be mutually co-dependent. For example, a low-income level hampers access to education, which, in turn, slows down the development in the area because it limits investments in specific technologies that depend on well-educated employees.

Development-related indicators also reflect new emerging anthropogenic pressures that can have a great impact on fish populations and fish harvests. For example, mining, especially the widespread open-pit mining in BF, increases pollution, both airborne and in surface runoff. Apart from biological pollution, which is low, heavy metal, chemical, and nutrient pollution from all sources have reached a "medium" level, as determined by expert opinion during the simulations exercise. Subsequently, high habitat degradation lowers species biodiversity, including fish, and hampers agricultural production by decreasing the organic content and bio-productivity of the soil, creating many hectares of barren land. Other development-related indicators (e.g., increasing population and urbanization) are also associated with pressures that are detrimental to the natural environment.

The Burkinabe economy has grown partly through the development of water infrastructures, such as man-made reservoirs, that secure water supplies for urban, industrial, and agricultural uses. However, these also might reduce fish habitat by creating additional fish migration barriers. Because this blocks the frequency of genetic exchange between fish populations, this could drastically lower the biodiversity of rivers and speed up the decline of some fish species. The level of water availability, which is medium, is connected to weather seasonality (the increasingly unpredictable durations of and shifts between dry and wet seasons) and the state of the existing water infrastructure. Further, it affects the size of the natural fish habitat and fish, which, combined with the diversity of species and their sensitivity to pollution, will impact the fish harvest potential. The latter can be further hindered by unregulated illegal practices, such as off-season fishing and illegal fishing equipment, both estimated to be high. Moreover, such illegal activities negatively impact the reproductive capacities of the fish and are inefficient in the long term. In summary, excessively intensive fish harvests, as a key source of food in BF, will continue to degrade the fish habitat and biodiversity, food security, and wellbeing of the population. 


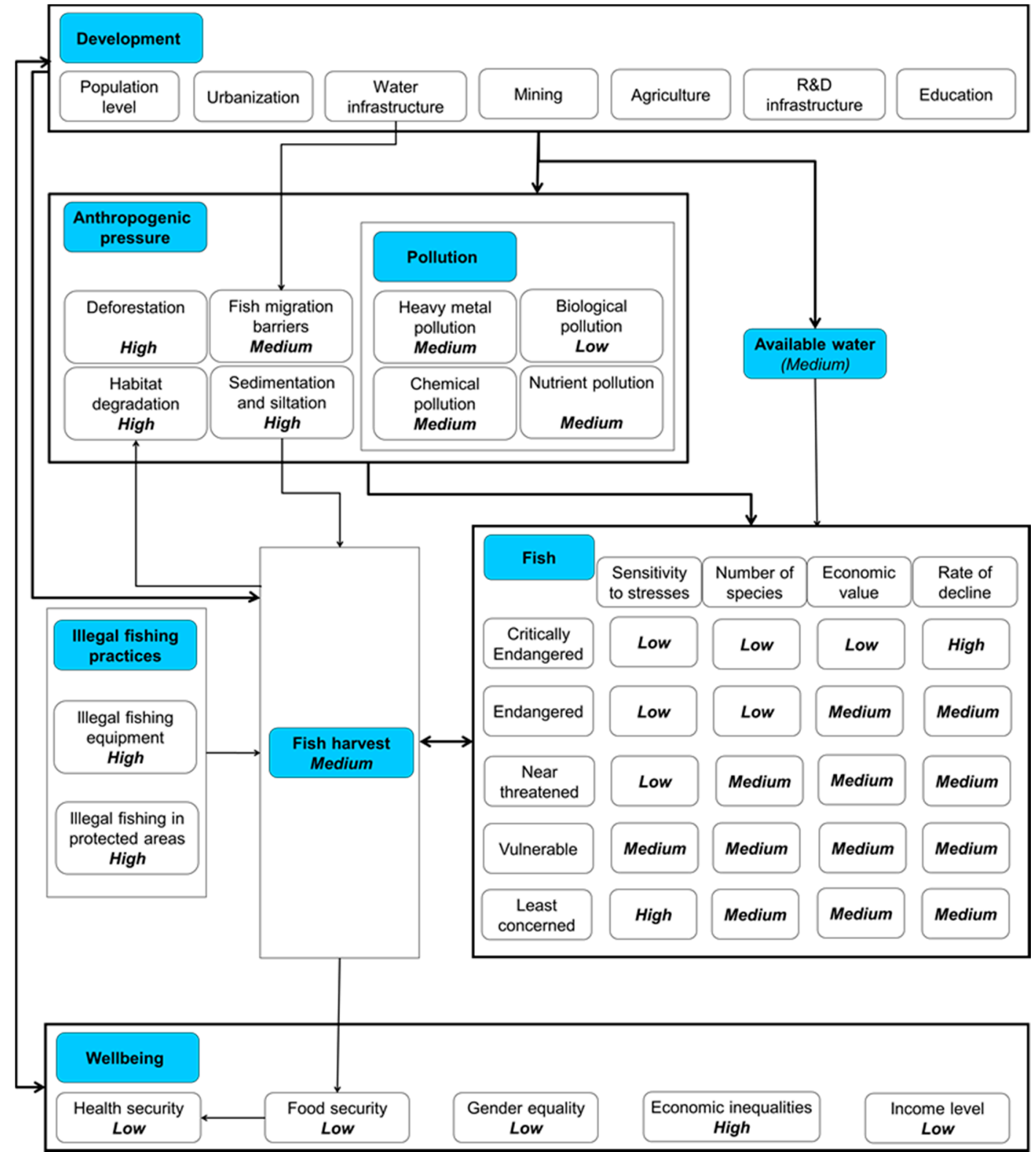

Figure 3. Causal map from the strategic simulations. The arrows show the interdependencies of the most important environmental and socio-economic factors of the Nakambe basin/BF system. The categories in italic and bold are the levels assigned by the participants to describe the current situation. The initial rating from 1 to 5 was recoded into Low (1-2), Medium (3), and High (4-5). R\&D: Research and development.

\subsubsection{Future Pathways for Sustainable Fisheries and Water Resources Management}

The strategic simulations exercise provided three future narratives that describe visions and the pathways towards achieving these visions: (i) Vision-priority focus on the water and environment sector, (ii) vision-priority focus on the food and fish sectors, and (iii) vision-priority focus on the economy and energy sectors.

\section{Vision-Priority Focus on Water and Environment Sector}

According to the participants to the strategic simulations, in order to prosper, the Nakambe basin requires sufficient access to water and conservation of its natural ecosystems. The implementation of this vision demands, firstly, the collaboration between various agencies from different government 
levels and support from responsible ministries for water and environmental resources, including the Ministry of Animal and Fish Resources, the Ministry in charge of Water Resources, the Ministry in charge of Environment, and the Ministry in charge of Agriculture. Secondly, the improvement of water resources management requires investments in cleaning and protection of the waterbodies by shoreline reforestation and delimitation of the special buffer zones in the whole Nakambe basin. Thirdly, the educational system should be improved to raise awareness and develop dialogue between conflicting local stakeholders. Finally, subsidies for private owners and small businesses related to the fisheries could reduce the illegal practices and increase the contribution of the local enterprises to the local, and country's budget. Additionally, the reduction of the negative impact of illegal fishing in protected areas and off-season fishing on the biodiversity of fish may be realized by creating a more business-friendly environment and by popularizing fish farming. Indeed, aside from a very few protected aquatic ecosystems, almost all fisheries exhibit a small fraction of their productive potential.

Overfishing is not the result of one single cause. It emerges from many factors linked in multiple, reinforcing patterns of behavior, which have persisted partly because of a failure to properly establish and implement fisheries management policies [4] (see the sector marked actions in Figure 4). A constellation of reinforcing feedbacks has caught BF's fisheries in a regeneration trap" [85]. Indeed, fishermen realize the highest profit rates in the fish value chain. This attracts men from all sectors of rural society to try fishing for part of the year, no matter how unskilled they are. While competition and relatively low yields force most to rely on other sources of income, fishing continues to attract very high participation rates. Profitability can drive a feedback that reinforces increases in the number of fishermen and, hence, fishing rates and harvest income, which feeds back to increase profits. Unchecked, this reinforcing feedback loop will continue to drive all values higher and higher up to the point of fisheries collapse. Such a reinforcing feedback loop increases the number of fishermen and sustains fishing rates too high to permit fish populations to restore their natural reproductive capacity (Figure 4).

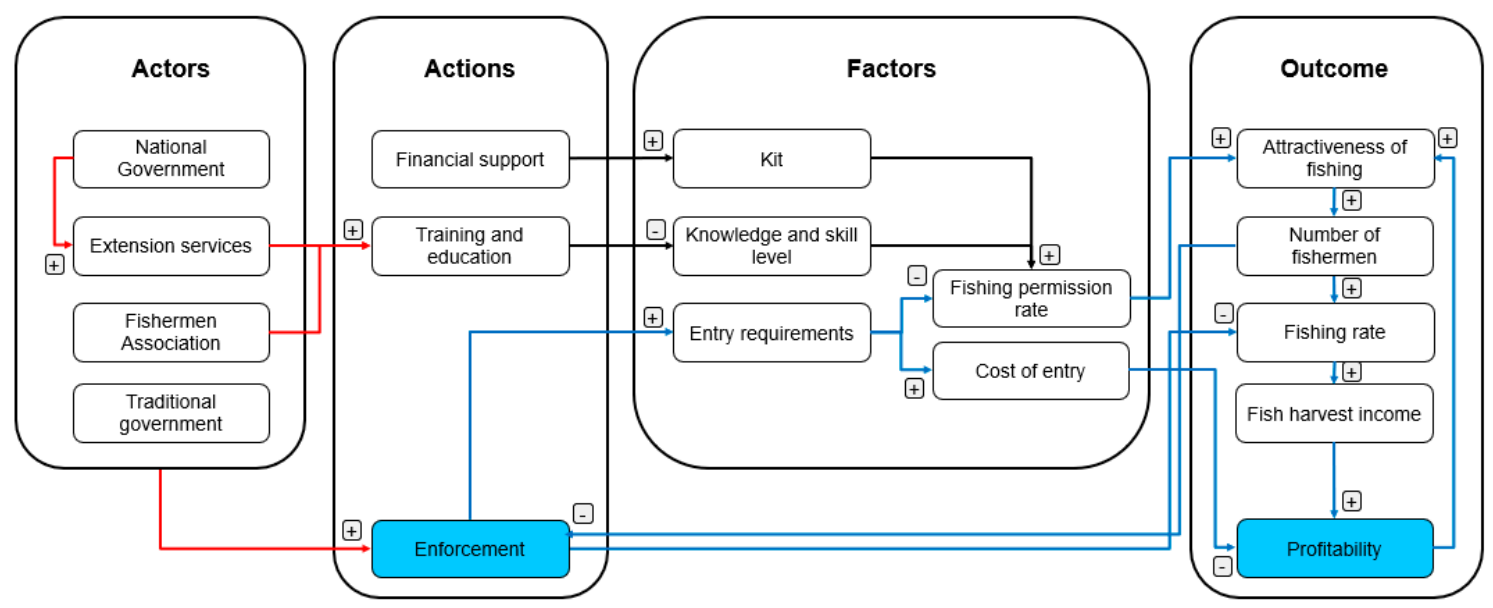

Figure 4. Governance failures leading to overfishing. The first variable to change is at the origin of the arrow, then the variable at the receiving end of the arrow will respond with a change. Regarding the "polarity", "+" shows that an increase or decrease in the first variable is matched by the same change in the receiving variable, "-" shows that the variables change in opposite directions. Actors: stakeholders for enforcement; actions: current measures; factors: elements that potentially could be provided by enforcement, training, and financial support to improve fishing governance; red arrows: interactions that are not established but could help make fisheries sustainable if instituted and established as standard parts of governance; blue arrows: feedback loops; outcome: potential results in terms of profitability; kit: fishermen' equipment. Source: modified after Sendzimir [85]. 


\section{Vision-Priority Focus on Food and Fish Sectors}

The second vision described by the participants to the strategic simulations consists of an integration of the investments in water and fish infrastructures to ensure food security and meet fish demand without complete depletion of the fish resources in the Nakambe basin. This would involve a series of transformations towards green energy sources so as to lower the negative impacts of water and air pollution resulting from fossil fuel energy by-products on both water and fish stock. The use of existing dams to produce hydro-energy will favor the productivity of the post-harvest facilities and crop harvesting. Further, investments in the creation of new dams and the development of irrigation, especially drip irrigation infrastructure, can contribute to develop the agricultural sector. Investments in fish stocking practices and new spawning grounds can help to sustain fish resources. Moreover, alternative energy sources (solar, wind) will contribute to minimize the negative impact of hydro-energy generation on the fish population. The improvement of the educational system is a core action in order to establish a skill base in BF society that can attract industries that exploit new ideas and innovate. Likewise, investments in the research and development will enhance the new possibilities that technology offers. Increased awareness of challenges by the general public and the policy sector, as well as the technical knowledge and soft skills (such as negotiating, leadership, and teamwork skills) are most important in implementing changes and transitioning towards a more green and efficient future.

\section{Vision-Priority Focus on Economy and Energy Sectors}

The third vision suggested by the participants to strategic simulations focused on the maintenance and the rehabilitation of existing water infrastructure to ensure better flow and quality of the water used for agriculture. For the participants to the strategic simulations, new dams should be equipped with fish passages to mitigate the negative effects of man-made barriers on fish reproduction, and biodiversity. To support farmers and the development of agriculture, a plan is needed to improve water delivery infrastructure. This would involve advancing drip irrigation technologies and reforming existing canal irrigation into more efficient systems.

Energy production can be addressed by diversifying the sources of energy to provide a secure and steady supply of energy to the widely distributed network of households and production facilities in BF. Further, the harmful impacts of hydroelectric dams on fish could be addressed by applying ideas from other countries, like the installation of nets (mesh, grating) for fish collection in the dams. Additionally, since climate change mandates the decarbonization of the economy, private owners and energy sector stakeholders could seize this challenge as an opportunity to shift from fossil fuel-based energy generation to cleaner solar energy. Since widespread open-pit mining fosters rural exodus and decreases the acreage of arable land, new employment policies could target youth and help adapt land newly reclaimed from mining to productive agricultural areas and invest in industrial mining. Finally, in this pathway, education is critical for the development of energy and economy sectors. Accordingly, curriculum reform should emphasize sustainable development and natural resources management as part of raising the general awareness about the current challenges of the basin. Finally, family planning will be promoted to stabilize the birth rate and the health of $\mathrm{BF}^{\prime}$ s residents.

\section{Further Questions}

The final visions for the Nakambe basin revealed a few tendencies among participants. Although we fostered a realistic approach among stakeholders, some of the results have a clearly aspirational element to them. Participants focused on the positive aspects of development and how to tackle the currently existing challenges, sometimes leaving out some of their negative effects that in reality would require countermeasures. A few topics were skimmed over or neglected by participants, for example, the budget. This was possibly due to a lack of time, sufficient data, or the variety of perspectives and goals represented among participants. Despite this, the visions presented above serve as an important 
source of knowledge about the region, stakeholders and decision makers in the region, their perception of the stressors, as well as their main aims and priorities for development.

\section{Discussion}

Multiple lines of evidence, e.g., literature reviews, interviews, and strategic simulations with stakeholders, were integrated to efficiently collect and combine data and research results of restricted availability. Indeed, the increasing recognition of the importance of epistemological pluralism [86] has deepened our appreciation of the value of local and traditional knowledge. This value is realized in part when research makes accessible to science and policy, knowledge and values that were established over decades of local experience [86-88] and constitute the ground on which certain societies judge their options. Further, it constitutes a source of detailed information about ecosystem processes and changes over long-time frames [86,89-91]. Thus, it can be used, especially, in a context where there are no documented data $[87,92,93]$, or when difficulties in accessing accurate data are prevalent, especially in Africa $[87,94]$.

The literature offered a dense and complete record of data and analyses of factors related to the sustainability of fisheries in $\mathrm{BF}$, including data on the variations of climatic factors. The interviews confirmed the patterns already observed from the literature. Indeed, resources users' experiences and observations can help to confirm system interactions that relate directly to their livelihoods $[95,96]$. However, they may lack an objective understanding of the underlying socio-ecological system (SES) processes, e.g., processes linking nature and society $[95,96]$ or gradual changes would sometimes escape their perception $[86,97]$.

\subsection{Stressors Interaction on Water and Fish Resources (Freshwater Ecosystem)}

Increasingly extreme weather patterns associated with climate change increase water loss due to increased evapotranspiration and, overall, the length of droughts, thereby exacerbating water shortages in BF. Increasing and interrelated demands for water and food from society, enhanced by demographic transition (including population growth), aggravates this water shortage. The nutrition transition specifically increases the demand for proteins and thus the demand for fish [68]. The response to these demands has aggravated damages of aquatic ecosystems. Evidence from the literature, interviews, and strategic simulations highlights the roles of the construction of dams, the expansion of irrigated agriculture, and overfishing as core pressures on the BF aquatic ecosystem.

Our results are similar in several respects to the study of Gebremedhin et al. [44]. They identify population growth as well as economic growth as the main drivers, and the major pressures consist of agriculture, dam construction, urbanization, and fisheries. However, our study describes more broad drivers, including climate change. It is worth noting that our study was extended to Sub-Saharan Africa and put an emphasis on the relation between fish and climate change. Further, our approach combines literature reviews with interviews. Instead, Gebremedhin et al. [44] focused on the Lake Tana in Ethiopia. Moreover, they describe the drivers, pressures, state, and impact based on the literature whilst responses were based on the literature, personal experience, and informal communication with fishermen, experts, and scientists [44].

Knudsen et al. [48] also applied a modified DPSIR, emphasizing drivers-pressure-state (DPS) to identify drivers for fishing pressure on the basis of ethnographic fieldwork and interviews in the Samsun fisheries on the Turkish Black Sea coast. These drivers include (i) fish demand and consumption (high-value fish); (ii) tax exemption on fuel price; (iii) increasing availability and adoption of new technology (electronic equipment); (iv) availability of fishing infrastructure; (v) structural flexibility allowing fishermen to switch between different regions, gear, and income generation activities; and (vi) poverty. Although the context of this study (i.e., costal fisheries) is different from our study and that of Gebremedhin et al. [44] (i.e., inland fisheries), they all highlight techniques adoption, fishermen resources poverty and hence dependence, the economic value of fisheries, and their importance in nutrition as sources of fishing pressure [44,48]. 
The strategic simulations suggested that industrial mining could replace open-pit mining as a policy response to the pollution resulting from the latter's activity. However, even though this activity can result in environmental damage, the literature highlights its socio-economic importance, especially for local households in BF [98,99]. For instance, Pokorny et al. [98] argue that artisanal gold mining can generate job opportunities and cash income for local households. Bazillier and Victoire [99] show that a $1 \%$ increase in the gold price leads to a $0.12 \%$ increase in the consumption of households located close to artisanal mines. This supports a strong positive impact of artisanal mining on consumption. They further found a marginally significant amelioration in children's health associated with the income effect of artisanal mines that may outweigh any pollution effect. Both surveys suggest that industrial gold mining has failed to exert a positive influence on local households compared to artisanal mining even though it may contribute much more at the more macro level, to the state budget by generating significant proportions of urgently needed revenues and taxes [98,99].

Driven in part by climate change, declining water levels in aquatic ecosystems are impacting, in turn, fish abundance and average size. While increasingly variable climate patterns are key to understanding current and future potential threats to waterbodies and fish in $\mathrm{BF}$, the trends cannot be generalized accurately to the whole country due to the very divergent climates from North to South. Indeed, the overall reliability of the climatic projection in West Africa and BF are challenged by the lack of observation data and monitoring in the region $[12,100,101]$, and the lack of adequate tools to assess the impacts of climate change on water resources at the local level [102]. Most projections are not developed in ways that can usefully be scaled down and inform science and policy at basin scales in West Africa. They offer globalized analysis, using large-scale resolution for their climatic models, averaging several hundreds of kilometers, sometimes including the whole country in one pixel of resolution [103-105]. To address this issue, BF should strengthen its climate-related information system by adopting a systematic approach for coordinating the development, archiving, and use of such information. As for climate development data, it is important to modernize the network of the meteorological stations (e.g., automatic weather stations). It is also important to strengthen the National Meteorological Agency (ANAM) as well as the network of meteorological stations across the country. In addition to modernizing equipment and infrastructures, it is essential to strengthen the human capital by upgrading the competences and building the capacities of the human resources dealing with climate information at national, regional, and local levels. In this context, it is crucial to consolidate the collaboration with the World Meteorological Organization (WMO).

It is almost impossible to dissociate climate change impacts from direct anthropogenic pressures on waterbodies and fish. Several papers emphasized that all the observed changes in aquatic systems and fish resources are caused by the combination of climate change and direct anthropogenic pressures, such as land degradation (e.g., deforestation, soil pollution), rather than by climate change alone $[4,73,81,106]$. For instance, Darwall et al. [107] imputed the decline of the fish average size and the shrinking of their distribution to climate change, water abstraction, dams construction, and overfishing.

Our results highlighted overexploitation as a pressure, which corroborates previous studies in $\mathrm{BF}[28,41,108,109]$. However, there is no unanimity in the scientific literature about the 'over-exploitation narrative' of freshwater fisheries [7,109,110]. Béné [109] and Béné and Russell [110] argue that, although the overexploitation in Lake Volta had already been suggested as a key factor more than 30 years ago and has been systematically brought forward in the past literature, the few time-series data available of fish landings over more than three decades do not substantiate this conclusion. Further, they highlighted that the discrepancies between official figures and the results of stock assessments may question the estimates, including the most rigorous ones. This is partly due to the lack of accurate data, including fish production figures [109,110], especially in BF. Chu et al. [7] also found that freshwater fisheries' overexploitation was not integrated as a pressure in the studies they reviewed.

Because of their structural complexity, the responses of animal and human communities may not be direct reactions to the rising trends of pressures and stressors. Despite the simple number of stressors in the ecosystems modified by humans, the interactions are complex with regard to 
the intensities and the temporal variation between them [111]. Secondly, tolerances of the fish population, derived from evolution or ecology, can modify biotic responses, such as biomass or species richness. In addition, biota can adapt to stressors and, likewise, biotic interactions can change at different stressors' levels [3,8,112]. Responses may vary within and between species, assemblages, and ecosystems; for example, headwaters compared to the middle of streams [113]. Thus, biotic interactions and responses may be not only linear but also non-linear or lagged [114].

Multiple lines of evidence enabled us to identify a diverse but not exhaustive list of pressures and stressors on BF aquatic ecosystems. Our results (Table 1) show that multiple stressors produce the same effect; therefore, it is likely that their combination implies interactions that amplify the effect of each other $[7,8,115,116]$. Evidence from marine environments already has shown that synergistic interaction between stressors, such as rising temperatures, biological invasions, and habitat destruction, exacerbates biodiversity loss and ecological degradation $[3,8,117,118]$. However, after analyzing three studies, Chu [7] found no consistent pattern; therefore, he highlighted that for additive, antagonistic, or synergistic interactions in multiple stressor assessments for freshwater fishes, interaction types depend chiefly on the species and life stage of interest, characteristics of the study ecosystem, indicators, and stressors (the same pressure can produce multiple stressors that affect state variables or indicators in different ways) [7]. We cannot on the basis of this study conclude whether the stressors in play are additive, synergetic, antagonistic, or an ecological surprise [7]. Therein lies a fundamental limitation of this research. Indeed, the study used a qualitative approach to understand stressor effects initially one by one, and then combined them [3,7]. This approach was motivated from a pragmatic point of view due to the difficulty to get and analyze accurate data specific to the species and the stressors.

Therefore, there is a need of further in-depth research using high-quality data with a wider scope (e.g., resolution in space and time) to test these hypotheses related to stressor effects and their interactions in the future. That could be done through experimental studies that compare controls to impacted ecosystems or replicate ecosystems exposed to similar stressors or gradients of stress [7]. Alternatively, meta-analyses could be performed [2,7,8,114].

The DPSIR has been subject to several criticisms, including (i) the risk of oversimplifying problems, (ii) the terminological unclarity, (iii) the lack of a methodological description to analyze disturbances $[47,119,120]$, (iv) the lack of a consistent structure for systematically dealing with specific factors within the model components [121], and (v) the relative neglect of the more elusive deeper socio-cultural factors that underlie environmental theme problems [121]. Therefore, its implementation can be challenging for both policymakers and scientists. However, integrating the DPSIR with other conceptual frameworks $[44,119,120]$ and more specific modelling tools $[44,122]$ can effectively overcome these limitations. Further, notwithstanding the abovementioned limitations, the DPSIR has been proven to be a useful tool to organize and present complex information (i.e., the causality flow between human activities and nature) in a comprehensive way and to explicitly identify interventions or policy actions that can be taken at any level of the cause-effect relationships $[43,44,121]$. Consequently, it is a valuable approach that can yield knowledge, communication, and awareness for integrated and effective scientific, political, and public decision-making processes regarding sustainability or other key societal objectives [121]. However, as argued by Chu [7], the suggested responses are only useful to minimize, not eliminate, stressor effects. The complete mitigation of stressors requires the elimination of the corresponding drivers, which is often impossible [7].

\subsection{From Stressors' Identification to Management Options}

Considering the impacts of such stressors, management options should integrate measures to address population growth, the enforcement of international and national strategies for sustainable fisheries management, and the promotion of alternative livelihoods for poverty reduction and sustainable food security, such as sustainable agriculture and aqc.

The first policy response could consist of measures for family planning and improved women's education to reduce population growth, as proposed by the African Union [44,81,123]. At the national 
level, to tackle the problem, the State has set up several population policies, including the 1991 National Population Policy (PNP), which was revised in 2000, to reach a balance between population growth and socio-economic development [124]; and the National Acceleration Plan for Family Planning to increase the rate of modern contraceptive prevalence from $22.5 \%$ in 2015 to $32 \%$ in 2020 and accelerate the demographic transition [125]. Zan [124] shows that the actions aiming at reducing the population resulted in a decrease of the syncretic fertility index, with the highest decline observed in women with higher fertility, that is to say women with no education, with primary education, or living in rural areas. In addition, the syncretic fertility index is decreasing more in women who do not use modern contraceptive methods $(62.9 \%$ against $37.10 \%)$. The author argues that this confirms a tendency to reduce fertility [124]. This observation suggests, he continues, the existence of traditional or natural methods to avoid pregnancy [124]. However, population and family planning policies have contributed much more to knowledge of contraceptive methods than to their use [124]. The adoption of family planning remains dependent on socio-economic factors, including the low level of education of women, hence the need for other development policies (e.g., education, urbanization, economic development). The literature shows that an increase in women's education can lead to a decline in fertility, even in the absence of family planning policies, because educated women are favorable to a lower fertility $[124,126]$. Given the direct negative correlation between the years of schooling of women and the fertility rate [127], an efficient starting point is the improvement of education and job opportunities for women [68]. These factors can contribute to the independence and free agency of women, e.g., their entry and participation, especially decision-making power, in the business sectors as well as governance [128]. For instance, women are already actively integrated in the fishing value chain, especially, in the area of fish processing and selling [4,28,41]. Therefore, strengthening this sector will also improve job opportunities and stimulate the participation of women in decision-making processes and administrative management of fisheries.

The second recommended policy response is the improvement of the implementation of strategies for sustainable fisheries. This requires the participation and empowerment of all actors [81]. Figure 4 presents four potential actors (viz. national government, traditional governance, extension services, fishermen's associations) who might contribute to the "protector" function either individually or in coordination with each other. Enforcement can be administered by agents of the traditional government (Kotigi or Tengsoba), by officers and/or members of fishermen's associations, and by agents of the national government or their regional proxies. Indeed, although trends show that traditional authorities' power is declining due to the spread of world religions, urbanization, and strengthening of republican governance $[4,129,130]$, they may revive under current national campaigns to decentralize. These may offer local traditional authorities the opportunity to have access to the decision-making sphere and to be among the strong actors [130] that significantly influence actions on the ground. Under the premise that republican governance hampers and widely lacks successful local policy implementation, the population loses trust of national authorities, and thus traditional local chiefs are regaining power [131]. They can be key persons for the improvement of communication between the local population and republican governance. This, in turn, could strengthen the integration of local knowledge and participatory approaches in management strategies [132] if local traditional authorities could be included. As for the extension services provided by republican government, they function in many nations as experts to train farmers, fishermen, and other users of natural resources in the skills needed to sustainably use those resources. Such agents are almost wholly lacking in BF's fisheries sector.

Proper enforcement, as shown in Figure 4, might imply that police controls in aquatic areas when fishing occurs, limit the fishing rate as well as how fishing occurs, controlling the kind of equipment ("kit") used, and the manner of its use. It can also control whether and how fishing occurs by granting licenses to a select a number of applicants and checking whether their knowledge and skill level qualifies them to fish. Such enforcement would further constrain fishing by raising the cost of entry to the fishing profession, thereby lowering the profitability, and, hence, the attractiveness of fishing. 
The factors (e.g., kit, skills, knowledge, and entry requirements) are elements by which enforcement agents might enable or deny access to fishing. Profitability is a determinant, since fishing provides cash income. For instance, decreasing profits due to increasing competition among fish processors is leading to a growing number of women to switch to other activities, such as gardening [110]. Profit can contribute to reduce the number of fishermen and, hence, fishing pressure. However, the implementation is challenging, because the state can barely muster the resources (personnel and equipment) to monitor and sanction illegal practices [41,130]. Previous studies in BF [41,130,133] show that organizing fishermen in associations and training them were successful instruments in implementing enforcement measures. As a result, fishermen associations respect such elements of governance control as limitations on the gear and mesh sizes, closed fishing seasons, and they collaborate in the monitoring, and add local initiatives for protecting aquatic resources. However, these studies further highlighted that the enforcement of fishing rights resulted in conflicting situations, because communities feel excluded from their resources for the benefit of individuals who have legal rights of use. This generated an increasing number of outsiders who trespassed on fishing grounds, especially in the case of concessions, which are granted as an "exclusive fishing right" [130,133]. However, as a policy open access also poses a risk for "tragedy of the commons" in fisheries [133]. Fishing is often only one part of the set of strategies of rural populations to diversify their economic activities in order to cope with risk $[110,134]$. Therefore, limiting access to fishing or reducing fishing profit can harm other activities and increase poverty levels among fishermen. Finding the balance between fishermen's needs and the preservation of aquatic resources is key.

In contrast to enforcement, the literature underlines incentives for current participants to leave the fisheries as a recommended policy to conserve aquatic resources [134]. However, the improvement of credit access would be conditional for the success of incentives. Indeed, the lack of formal credit facilities forces fishers to turn to informal credit providers, facing often an exploitive situation [41,110]. The State can create better conditions to increase opportunities, enable environment for investment, credit at low rate, simplify the legal framework, and provide training. These measures should raise the awareness among stakeholders about the positive effects of sustainable natural resources management and at the same time empower them in this area. Indeed, despite slight progress, the literature has reported a limited ecological awareness of local actors [41,108,135].

The third recommendation is the provision of alternative livelihoods, such as aqc and agriculture, to compensate reduced incomes, and to prevent further poverty and food insecurity. Béné and Russell [110] demonstrated in Volta Lake (Ghana) and in Bagré (BF) that the diversification of income sources is a determinant of fishermen's poverty status. Indeed, they argue that the fishermen depending on only fishing are among the poor group whilst the better off have diversified activities, including on- and off-farm activities. First of all, thousands of people in BF are dependent on fisheries [136] for income and subsistence. The secondarily generated income through fishing enables them to finance their medical supply, schooling for their children, and investments in agricultural activities [4]. Without alternative livelihoods that generate consistent income, people will increase their fishing activity and the use of illegal fishing techniques, regardless of fishing laws. Therein, the development of aqc has a high potential $[69,70,137,138]$ and is regarded as " $(.$.$) the sole solution for boosting fish stocks$ in the Sahel region" [70]. However, direct and indirect interactions between aqc practice and the environment needs to be taken into account [139]. Besides the recovery of fish stocks by reducing the pressure of overfishing and proper active restocking measures $[140,141]$, it can contribute to the provision of an alternative livelihood and protein supply. However, this approach should comply with the national regulation regarding the introduction of new species; the native fish population could be promoted rather than new alien invasive species. Indeed, the introduction of new species can either lead to an adaptation to ecological conditions; non-adaptation of the species, which results in its disappearance [4]; or other undesirable effects [108]. The failure of restocking can be attributed to fishermen's insufficient knowledge about fish ecology or even overfishing [108]. Hence, there is a need for capacity building for fishermen through training and better monitoring of the fisheries 
during the restocking process. In addition, the implementation of the aqc must be accompanied by an environmental impact assessment.

Secondly, since agriculture is the main activity of the majority of BF's rural population, including fishermen [41,108,109], the development of this sector can limit the rush over fish resources. However, considering the current pressure of agriculture on the aquatic ecosystem, the diffusion of more sustainable agricultural techniques is required.

\section{Conclusions}

Our study contributed to the identification of multiple stressors and their interactions that influence the sustainability of inland fisheries in BF's aquatic ecosystems. This was done by combining evidence from literature reviews, expert interviews, and strategic simulations with fisheries stakeholders. It allowed the construction of a causal map of the drivers, pressures, state, impacts, and responses using the DPSIR framework and a causal map of the current situation leading to future pathways about the water and fisheries management in BF. By providing simple causal maps, independent of vocabularies specific to separate disciplines, both models enable closer communication between researchers and decision-makers and open a debate about a holistic approach towards sustainable fisheries and aquaculture development to meet urgent needs to secure livelihood and food access for the population in BF. Such tools are useful in integrating inputs from stakeholders at all levels and in different sectors of the society. In this case, these models helped to better combine waterand fish-related ecosystem services' contributions to human well-being and the need to preserve these resources in the long term through a better knowledge (both indigenous and scientific) of their interaction and possible effective societal responses. This, in turn, highlights the importance of restoring the correct functionality of aquatic ecosystem services, especially in rivers belonging to very large catchments and on which many different geographical, socio-cultural, and political realities co-exist (e.g., Volta River flowing from BF into Ghana).

The water level was confirmed to currently decrease and to impact, in turn, fish abundance and average size, as a result of the current decrease of the total annual precipitation and the increase of annual precipitation variability. However, the uncertainties regarding the future precipitation patterns in the region (cf. Sahel/West Africa) may invalidate this hypothesis in the near future. Fish productivity, abundance, and average size were shown as the biotic indicators that are most recognized as being impacted nowadays by climate change in BF. The massive construction of dams and intensive agriculture have affected the status of aquatic ecosystems and, hence, of fish. With regard to overfishing, in addition to the lack of enforcement, profitability seems a determinant of overuse, since it drives a feedback loop, which reinforces the increase in the number of fishers and, consequently, fishing rates and incomes, which feedback to increase profits.

The gained understanding, from diverse perspectives, on the effects of multiple socio-ecological stressors on aquatic (water, fish) ecosystems across temporal and spatial scales in BF can be used to improve the effectiveness, efficacy, and sustainability of the management of these ecosystems in the context of climate change. Indeed, given the multiple biological, physical, and socio-economic stressors that affect the structure and functioning of aquatic ecosystems in BF, it is urgent to implement the management options and mitigation measures outlined in the present paper to ensure the long-term sustainability of fisheries and their vital contribution to food security and livelihoods in the country. The insights provided by the present paper on socio-ecological stressors affecting aquatic ecosystems and implications for sustainable management of fisheries in BF are valid for the other countries in West Africa, Sahel region, and Sub-Saharan Africa at large. Nevertheless, further research is needed on the interaction of multiple stressors and their impacts on the state of aquatic ecosystems in arid and semi-arid regions, to provide sound evidence to policy- and decision-makers. 
Author Contributions: Conceptualization, V.-P.S., P.T., J.C.R., H.E.B., L.J.H., M.K., P.M. (Piotr Magnuszewski), J.P., J.S. and A.H.M.; Data curation, V.-P.S., J.C.R., L.J.H., M.K., P.M. (Piotr Magnuszewski), J.P. and A.H.M.; Formal analysis, V.-P.S., J.C.R., L.J.H., M.K., P.M. (Piotr Magnuszewski), J.P. and J.S.; Funding acquisition, A.H.M.; Investigation, V.-P.S., J.C.R., L.J.H., M.K., P.M. (Piotr Magnuszewski) and J.P.; Methodology, V.-P.S., P.T., J.C.R., H.E.B., L.J.H., M.K., P.M. (Piotr Magnuszewski), J.P., J.S. and A.H.M.; Project administration, P.T. and A.H.M.; Resources, V.-P.S., J.C.R., L.J.H., M.K., P.M. (Piotr Magnuszewski), J.P. and J.S.; Software, V.-P.S., J.C.R., L.J.H., M.K., P.M. (Piotr Magnuszewski), J.P. and J.S.; Supervision, P.T., H.E.B., G.S., S.V. and A.H.M.; Validation, V.-P.S., J.C.R., L.J.H., M.K., P.M. (Piotr Magnuszewski), J.P. and A.H.M.; Visualization, V.-P.S., L.J.H., M.K., P.M. (Piotr Magnuszewski), J.P. and J.S.; Writing-original draft, V.-P.S., J.C.R., L.J.H., M.K., P.M. (Piotr Magnuszewski), J.P. and J.S.; Writing-review and editing, V.-P.S., P.T., H.E.B., M.K., P.M. (Piotr Magnuszewski), P.M. (Paul Meulenbroek), J.S., G.S., S.V. and A.H.M. All authors have read and agreed to the published version of the manuscript.

Funding: This research project SUSFISH-plus (project166) was funded by APPEAR, the Austrian Partnership Programme in Higher Education and Research for Development, a programme funded by the Austrian Development Cooperation (ADC) and implemented by the Austrian Agency for International Cooperation in Education and Research (OeAD), see also https://appear.at/en/. Grant number OEZA 0894-00/2014 and The APC was funded by SUSFISH-plus (project166).

Acknowledgments: We thank all interviewees for sharing their time, knowledge and opinions with us. We are also grateful to all members of the project Sustainable Management of Water and Fish Resources in Burkina Faso (SUSFISH-plus), in which this research is embedded, for their team work and spirit. SUSFISH-plus aims at establishing sustainable socio-economic fisheries and water management through the improvement of higher education and governance in Burkina Faso [39-41].

Conflicts of Interest: The authors declare no conflict of interest. The funders had no role in the design of the study; in the collection, analyses, or interpretation of data; in the writing of the manuscript, or in the decision to publish the results.

\section{Appendix A}

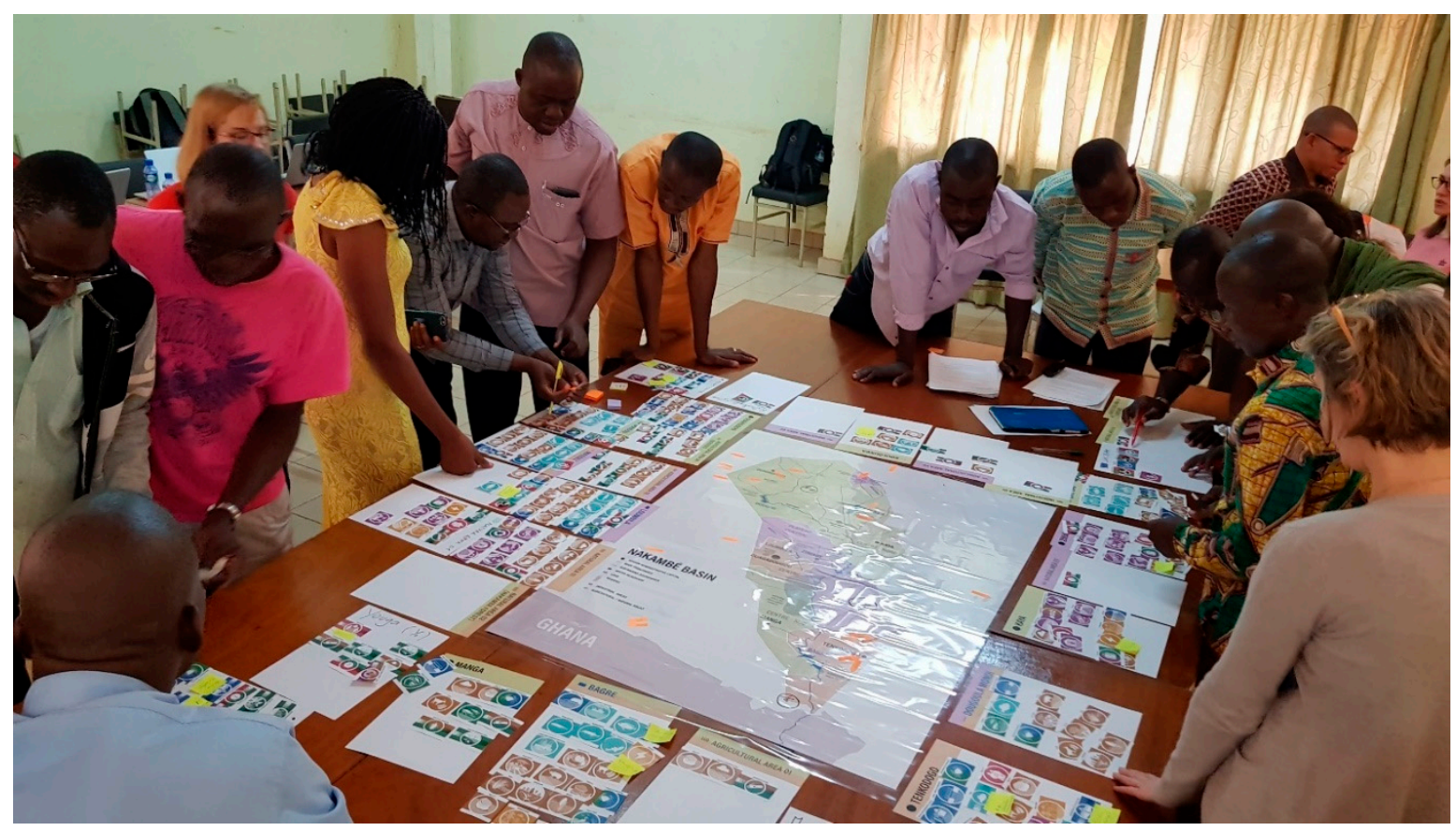

Figure A1. Participants describing the current situation of Nakambe Basin, during the strategic simulations in Ouagadougou. 


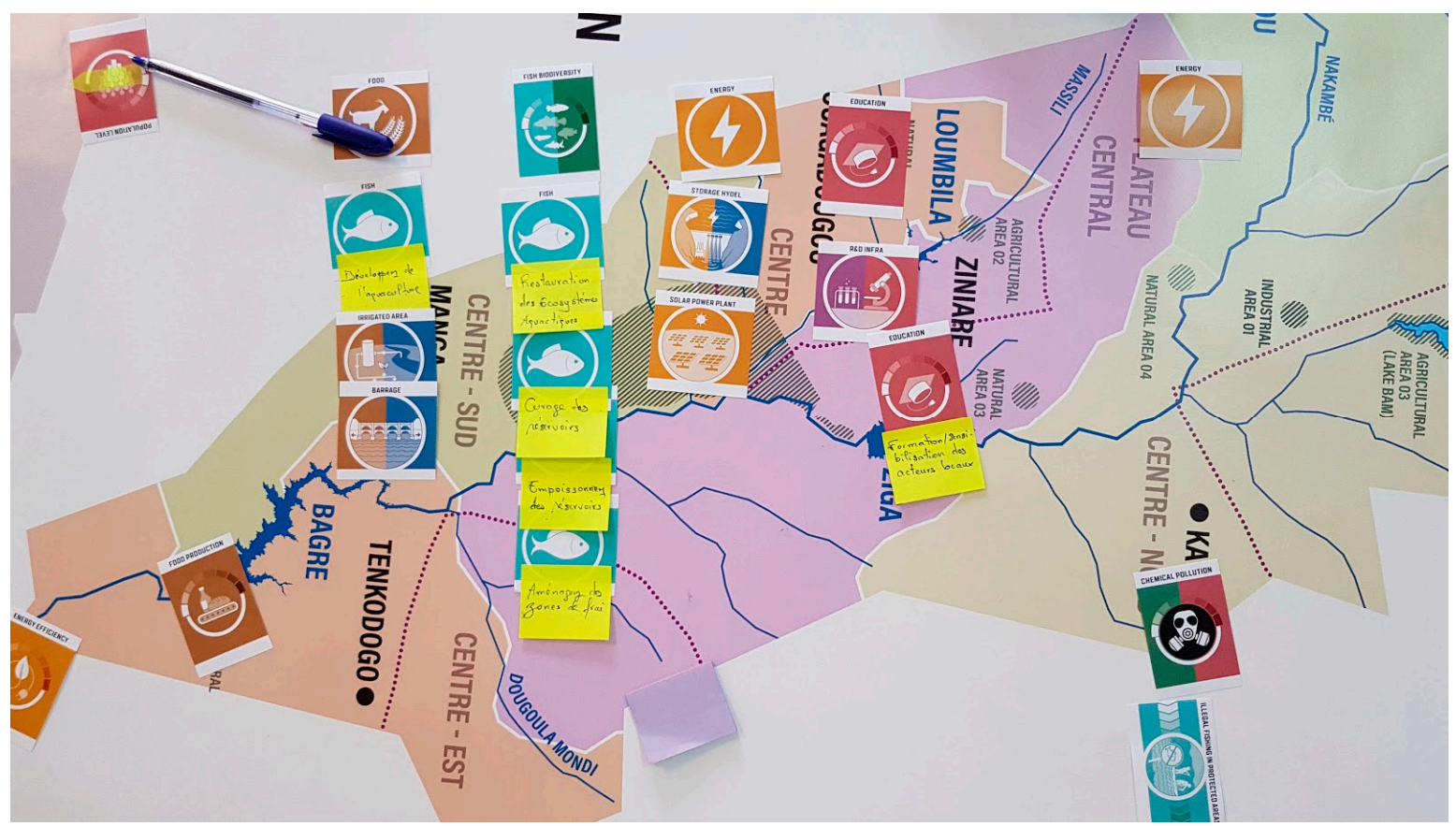

Figure A2. Representation by the participants to the strategic simulations of the future pathways regarding the vision-priority focus on economy and energy sectors in Nakambe Basin.

\section{References}

1. Dudgeon, D.; Arthington, A.H.; Gessner, M.O.; Kawabata, Z.I.; Knowler, D.J.; Lévêque, C.; Naiman, R.J.; Prieur-Richard, A.H.; Soto, D.; Stiassny, M.L.J.; et al. Freshwater biodiversity: Importance, threats, status and conservation challenges. Biol. Rev. Camb. Philos. Soc. 2006, 81, 163-182. [CrossRef] [PubMed]

2. Ormerod, S.J.; Dobson, M.; Hildrew, A.G.; Townsend, C.R. Multiple stressors in freshwater ecosystems. Freshw. Biol. 2010, 55, 1-4. [CrossRef]

3. Jackson, M.C.; Loewen, C.J.G.; Vinebrooke, R.D.; Chimimba, C.T. Net effects of multiple stressors in freshwater ecosystems: A meta-analysis. Glob. Chang. Biol. 2016, 22, 180-189. [CrossRef]

4. Ouedraodogo, R. Fish and Fisheries Prospective in Arid Inland Waters of Burkina Faso, West Africa. Ph.D. Thesis, University of Natural Resources and Life Sciences (BOKU), Vienna, Austria, 2010.

5. Malqmqvist, B.; Rundle, S. Threats to the running water ecosystems of the world. Environ. Conserv. 2002, 29, 134-153. [CrossRef]

6. Sanderson, E.W.; Jaiteh, M.; Levy, M.A.; Redford, K.H.; Wannebo, A.V.; Woolmer, G. The human footprint and the last of the wild. Bioscience 2002, 52, 891-904. [CrossRef]

7. Chu, C.; Barker, J.; Gutowsky, L.; de Kerckhove, D. A Conceptual Management Framework for Multiple Stressor Interactions in Freshwater Lakes and Rivers; Ontario Ministry of Natural Resources and Forestry: Peterborough, ON, Canada, 2018.

8. Crain, C.M.; Kroeker, K.; Halpern, B.S. Interactive and cumulative effects of multiple human stressors in marine systems. Ecol. Lett. 2008, 11, 1304-1315. [CrossRef]

9. Halpern, B.S.; Selkoe, K.A.; Micheli, F.; Kappel, C.V. Evaluating and ranking the vulnerability of global marine ecosystems to anthropogenic threats. Conserv. Biol. 2007, 21, 1301-1315. [CrossRef]

10. Schmutz, S.; Sendzimir, J. Science for governing towards a sustainable future. In Riverine Ecosystem Management; Schmutz, S., Sendzimir, J., Eds.; Springer: Cham, Switzerland, 2018; ISBN 9783319732497.

11. Melcher, A.H.; Ouedraogo, R.; Schmutz, S. Spatial and seasonal fish community patterns in impacted and protected semi-arid rivers of Burkina Faso. Ecol. Eng. 2012, 48, 117-129. [CrossRef]

12. Allan, J.D.; Abell, R.; Hogan, Z.E.B.; Revenga, C.; Taylor, B.W.; Welcomme, R.L.; Winemiller, K. Overfishing of Inland Waters. Bioscience 2005, 55, 1041-1051. [CrossRef]

13. FAO. The State of World Fisheries and Aquaculture 2018-Meeting the Sustainable Development Goals; FAO: Rome, Italy, 2018; ISBN 9789251305621. 
14. Encyclopaedia Britannica Sahel. Region, Africa. Available online: https://www.britannica.com/place/Sahel (accessed on 22 April 2019).

15. Climate Investment Funds Burkina Faso. Available online: https://www.climateinvestmentfunds.org/ country/burkina-faso (accessed on 2 October 2018).

16. World Bank Burkina Faso: Overview. Available online: http://www.worldbank.org/en/country/burkinafaso/ overview\#1 (accessed on 2 October 2018).

17. Dresch, J.; Echenberg, M.; Guiguemde, P.H.; Deschamps, H.J. Burkina Faso. Available online: https://www.britannica.com/place/Burkina-Faso\#ref54885 (accessed on 2 October 2018).

18. SP/CONEDD. Evaluation de la Vulnérabilité et des Capacités D'adaptation aux Changements Climatiques du Burkina Faso; SP/CONEDD: Ouagadougou, Burkina Faso, 2006.

19. World Bank Burkina Faso. Available online: https://data.worldbank.org/indicator/NY.GDP.PCAP.CD? locations $=B F \& v i e w=$ chart (accessed on 30 January 2020).

20. UNDP Human Development Indices and Indicators: 2018 Statistical Update. Briefing Note for Countries on the 2018 Statistical Update: Burkina Faso. Available online: http://www.hdr.undp.org/sites/all/themes/hdr_ theme/country-notes/BFA.pdf (accessed on 9 October 2018).

21. African Development Bank Country Strategy Paper (CSP) 2017-2021: Burkina Faso. Available online: https://www.afdb.org/en/documents/document/burkina-faso-country-strategy-paper-2017-2021-98046/ (accessed on 27 November 2018).

22. Fowe, T.; Karambiri, H.; Paturel, J.E.; Poussin, J.C.; Cecchi, P. Water balance of small reservoirs in the Volta basin: A case study of boura reservoir in Burkina Faso. Agric. Water Manag. 2015, 152, 99-109. [CrossRef]

23. Boelee, E.; Cecchi, P.; Koné, A. Health Impacts of Small Reservoirs in Burkina Faso; IWMI Working Paper; International Water Management Institute: Colombo, Sri Lanka, 2009; ISBN 978-92-9090-717-6.

24. Venot, J.-P.; Cecchi, P. Valeurs d'usage ou performances techniques: Comment apprécier le rôle des petits barrages en Afrique subsaharienne? Cah. Agric. 2011, 20, 112-117.

25. Jaime, C.R. GIS Based Analysis of the Environmental and Societal Importance of the Reservoirs in Burkina Faso. Master's Thesis, University of Natural Resources and Life Sciences (BOKU), Vienna, Austria, 2019.

26. Cecchi, P.; Meunier-Nikiema, A.; Moiroux, N.; Sanou, B. Towards an atlas of lakes and reservoirs in Burkina Faso. In Small Reservoirs Toolkit; Andreini, M., Schuetz, T., Harrington, L., Eds.; IWMI: Battaramulla, Sri Lanka, $2009 ;$ p. 23.

27. Lemoalle, J.; Condappa, D. Water Atlas of the Volta Basin-Atlas De L'Eau Dans Le Bassin De La Volta; Challenge Program on Water and Food and Institut de Recherche pour le Développement: Colombo, Sri Lanka; Marseille, France, 2009; ISBN 9789295090002.

28. Meulenbroek, P.; Stranzl, S.; Oueda, A.; Sendzimir, J.; Mano, K.; Kabore, I.; Ouedraogo, R.; Melcher, A. Fish communities, habitat use, and human pressures in the Upper Volta basin, Burkina Faso, West Africa. Sustainability 2019, 11, 5444. [CrossRef]

29. Ministère de l'Environnement et du Cadre de Vie. Burkina Faso National Climate Change Adaptation Plan (NAP); Ministère de l'Environnement et du Cadre de Vie: Ouagadougou, Burkina Faso, 2007; p. 152.

30. Baijot, E.; Moreau, J.; Bouda, S. Aspects Hydrobiologiques Et Piscicoles Des Retenues D'Eau En Zone Soudano-Sahélienne. Le Cas Du Burkina Faso; Centre Technique de Coopération Agricole et Rurale (CTA): Brussels, Belgium, 1994; ISBN 9290811242.

31. Paugy, D.; Fermon, Y.; Abban, K.E.; Diop, M.E.; Traoré, K. Onchocerciasis control programme in West Africa: A 20-year monitoring of fish assemblages. Aquat. Living Resour. 1999, 12, 363-378. [CrossRef]

32. Mano, K. Fish Assemblages and Aquatic Ecological Integrity in Burkina Faso. Ph.D. Thesis, University of Natural Resources and Life Sciences (BOKU), Vienna, Austria, 2016.

33. Myers, B.J.E.; Lynch, A.J.; Bunnell, D.B.; Chu, C.; Falke, J.A.; Kovach, R.P.; Krabbenhoft, T.J.; Kwak, T.J.; Paukert, C.P. Global synthesis of the documented and projected effects of climate change on inland fishes. Rev. Fish Biol. Fish. 2017, 27, 339-361. [CrossRef]

34. Root, T.L.; Price, J.T.; Hall, K.R.; Schneider, S.H. Fingerprints of global warming on wild animals and plants. Nature 2003, 421, 57-60. [CrossRef] [PubMed]

35. Staudt, A.; Leidner, A.K.; Howard, J.; Brauman, K.A.; Dukes, J.S.; Hansen, L.J.; Paukert, C.; Sabo, J.; Solórzano, L.A. The added complications of climate change: Understanding and managing biodiversity and ecosystems. Front. Ecol. Environ. 2013, 11, 494-501. [CrossRef] 
36. Hering, D.; Carvalho, L.; Argillier, C.; Beklioglu, M.; Borja, A.; Cardoso, A.C.; Duel, H.; Ferreira, T.; Globevnik, L.; Hanganu, J.; et al. Managing aquatic ecosystems and water resources under multiple stress-An introduction to the MARS project. Sci. Total Environ. 2015, 503, 10-21. [CrossRef]

37. Lamnek, S.; Krell, C. Qualitative Sozialforschung; Beltz Verlag: Weinheim, Basel, 2005; ISBN 9783621283625.

38. Kraft, K.H.; Brown, C.H.; Nabhan, G.P.; Luedeling, E.; Ruiz, J.D.J.L.; d'Eeckenbrugge, G.C.; Hijmans, R.J.; Gepts, P. Multiple lines of evidence for the origin of domesticated chili pepper, Capsicum annuum, in Mexico. Proc. Natl. Acad. Sci. USA 2014, 111, 6165-6170. [CrossRef]

39. APPEAR Sustainable Management of Water and Fish Resources in Burkina Faso. Available online: https://appear.at/en/projects/current-projects/project-websites/project166-susfish-plus/ (accessed on 10 February 2020).

40. Susfish Project Overview. Available online: http://susfish.boku.ac.at/contao/index.php/beispiel-startseite. html (accessed on 10 February 2020).

41. Slezak, G.; Sendzimir, J.; Ouedraogo, R.; Meulenbroek, P.; Savadogo, M.; Kabore, C.; Oueda, A.; Toe, P.; Zerbo, H.; Melcher, A. Fishing for food and food for fish-Negotiating long-term, sustainable food and water resources in a transdisciplinary research project in Burkina Faso. In Towards Shared Research: Participatory and Integrative Approaches in Researching African Environments; Zingerli, C., Haller, T., Eds.; Transcript Verlag: Bielefeld, Germany, 2020; pp. 125-165. ISBN 9783839451502.

42. Patton, M.Q. How to Use Qualitative Methods in Evaluation; Sage: London, UK, 1987; ISBN 0803931298.

43. Bradley, P.; Yee, S. Using the DPSIR Framework to Develop a Conceptual Model: Technical Support Document; US Environmental Protection Agency, Office of Research and Development, Atlantic Ecology Division: Narragansett, RI, USA, 2015.

44. Gebremedhin, S.; Getahun, A.; Anteneh, W.; Bruneel, S.; Goethals, P. A Drivers-Pressure-State-Impact-Responses framework to support the sustainability of fish and fisheries in Lake Tana, Ethiopia. Sustainability 2018, 10, 2957. [CrossRef]

45. Agyemang, I.; McDonald, A.; Carver, S. Application of the DPSIR framework to environmental degradation assessment in northern Ghana. Nat. Resour. Forum 2007, 31, 212-225. [CrossRef]

46. Niemeijer, D.; de Groot, R.S. Framing environmental indicators: Moving from causal chains to causal networks. Environ. Dev. Sustain. 2008, 10, 89-106. [CrossRef]

47. Martins, J.H.; Camanho, A.S.; Gaspar, M.B. A review of the application of driving forces-PressureState-Impact-Response framework to fisheries management. Ocean. Coast. Manag. 2012, 69, $273-281$. [CrossRef]

48. Knudsen, S.; Zengin, M.; Koçak, M.H. Identifying drivers for fishing pressure. A multidisciplinary study of trawl and sea snail fisheries in Samsun, Black Sea coast of Turkey. Ocean. Coast. Manag. 2010, 53, 252-269. [CrossRef]

49. Mangi, S.C.; Roberts, C.M.; Rodwell, L.D. Reef fisheries management in Kenya: Preliminary approach using the driver-pressure-state-impacts-response (DPSIR) scheme of indicators. Ocean. Coast. Manag. 2007, 50, 463-480. [CrossRef]

50. Kelble, C.R.; Loomis, D.K.; Lovelace, S.; Nuttle, W.K.; Ortner, P.B.; Fletcher, P.; Cook, G.S.; Lorenz, J.J.; Boyer, J.N. The EBM-DPSER conceptual model: Integrating ecosystem services into the DPSIR framework. PLoS ONE 2013, 8. [CrossRef] [PubMed]

51. European Commission Analysis of Pressures and Impacts. In Guidance Document No 3; OPOCE: Luxembourg, 2003.

52. Harvey, S.; Liddell, A.; McMahon, L. Windmill 2009; O’Neill, K., Ed.; Dutch University Press: London, UK, 2009; ISBN 9781857175882.

53. Duke, R.D.; Geurts, J.L.A. Policy Games for Strategic Management; Rozenberg Publishers: Amsterdam, The Netherlands, 2004; ISBN 9036193419.

54. Solinska-Nowak, A.; Magnuszewski, P.; Curl, M.; French, A.; Keating, A.; Mochizuki, J.; Liu, W.; Mechler, R.; Kulakowska, M.; Jarzabek, L. An overview of serious games for disaster risk management-Prospects and limitations for informing actions to arrest increasing risk. Int. J. Disaster Risk Reduct. 2018, 31, 1013-1029. [CrossRef]

55. Wada, Y.; Vinca, A.; Parkinson, S.; Willaarts, B.A.; Magnuszewski, P.; Mochizuki, J.; Mayor, B.; Wang, Y.; Burek, P.; Byers, E.; et al. Co-designing Indus water-energy-land futures. One Earth 2019, 1, 185-194. [CrossRef] 
56. Van Notten, P. Scenario development: A typology of approaches. In Think Scenarios. Rethink Education; OECD, Ed.; OECD: Paris, France, 2006; pp. 69-92. ISBN 9789264023642.

57. Volkery, A.; Ribeiro, T. Scenario planning in public policy: Understanding use, impacts and the role of institutional context factors. Technol. Forecast. Soc. Chang. 2009, 76, 1198-1207. [CrossRef]

58. Lonsdale, K.G.; Downing, T.E.; Nicholls, R.J.; Parker, D.; Vafeidis, A.T.; Dawson, R.; Hall, J. Plausible responses to the threat of rapid sea-level rise in the Thames Estuary. Clim. Chang. 2008, 91, 145-169. [CrossRef]

59. Toth, F.L.; Hizsnyik, E. Managing the inconceivable: Participatory assessments of impacts and responses to extreme climate change. Clim. Chang. 2008, 91, 81-101. [CrossRef]

60. Stefanska, J.; Magnuszewski, P.; Sendzimir, J.; Romaniuk, P.; Taillieu, T.; Dubel, A.; Flachner, Z.; Balogh, P. A gaming exercise to explore problem-solving versus relational activities for river floodplain management. Environ. Policy Gov. 2011, 21, 454-471. [CrossRef]

61. Parson, E.A. A Global Climate-Change Policy Exercise: Results of a Test Run, July 27-29, 1995; IIASA Working Paper, WP-96-090; International Institute for Applied Systems Analysis: Laxenburg, Austria, 1996.

62. Hundscheid, L.J. Aquaculture in Burkina Faso-A Niche in Transition. Master's Thesis, University of Natural Resources and Life Sciences (BOKU), Vienna, Austria, 2019.

63. Thompson, W.S. Population. Am. J. Sociol. 1929, 34, 959-975. [CrossRef]

64. Kirk, D. Demographic transition theory. Popul. Stud. 1996, 50, 361-387. [CrossRef] [PubMed]

65. Mendez, M.A.; Popkin, B.M. Globalization, urbanization and nutritional change in the developing world. Electron. J. Agric. Dev. Econ. 2004, 1, 220-241.

66. World Bank. The World Bank Group A to Z 2016; World Bank: Washington, DC, USA, 2016; ISBN 978-1-4648-0655-1.

67. Sawadogo, J.M. Coping With Less Rain in Burkina Faso. Available online: https://www.un.org/africarenewal/ magazine/july-2007/coping-less-rain-burkina-faso (accessed on 1 April 2019).

68. Popkin, B. What is The Nutrition Transition. Available online: http://www.cpc.unc.edu/projects/nutrans/ whatis (accessed on 20 June 2018).

69. Satia, B.P. Regional review on status and trends in aquaculture development in Sub-Saharan Africa-2010. In FAO Fisheries and Aquaculture Circular No. 1061/4; FAO, Ed.; FAO: Rome, Italy, 2017; p. 191.

70. Amoussou, O.T.; Youssao, I.A.K.; Toguyéni, A. Improving aquaculture production in the Kou valley, Burkina Faso. In Agricultural Innovations for Sustainable Development: Contributions from the 3rd Africa-Wide Women and Young Professionals in Science Competitions; Francis, J.A., Ed.; Technical Centre for Agricultural and Rural Cooperation (CTA): Wageningen, The Netherlands; Forum for Agricultural Research in Africa (FARA): Accra, Ghana, 2014; Volume 4, pp. 187-194.

71. Awotwi, A.; Kumi, M.; Jansson, P.E.; Yeboah, F.; Nti, I.K. Predicting hydrological response to climate change in the White Volta catchment, West Africa. J. Earth Sci. Clim. Chang. 2015, 6, 1-7.

72. Savadogo, A.-S. Water Resource Management in Burkina Faso. Available online: https://www.wateraid.org/ search/wasearch (accessed on 3 March 2020).

73. Diarra, D.Z. Impacts Des Changements Climatiques En Afrique De l'Ouest; Direction Nationale de la Météorologie: Bamako, Mali, 2009.

74. Stücklin, S.B.; Frei, K. Between water spirits and market forces: Institutional changes in the Niger inland delta fisheries among the Somono and bozo fishermen of Wandiaka and Daga-Womina (Mali). In Disputing the Floodplains: Institutional Change and the Politics of Resource Management in African Wetlands; Haller, T., Ed.; Brill: Leiden, The Netherland, 2010; pp. 77-119.

75. Barrat, J.-M. Changements Climatiques En Afrique De l'Ouest Et Conséquences Sur Les Eaux Souterraines. Rapport OSS-GICRESAIT no 13; Observatoire du Sahara et du Sahel (OSS): Tunis, Tunisia, 2012.

76. Yang, T.; Cui, T.; Xu, C.-Y.; Ciais, P.; Shi, P. Development of a new IHA method for impact assessment of climate change on flow regime. Glob. Planet. Chang. 2017, 156, 68-79. [CrossRef]

77. Touré, A. Changement climatique. In Sédentarisation Et Adaptation Des Pêcheurs Du Delta Central Du Niger: Cas Des Communes De Mopti Et Konna; Université de Bamako: Bamako, Mali, 2006.

78. Paillaugue, J. Climate Change Impacts on Fish Resources in Burkina Faso. Master's Thesis, University of Natural Resources and Life Sciences (BOKU), Vienna, Austria, 2019.

79. Schinegger, R.; Trautwein, C.; Melcher, A.; Schmutz, S. Multiple human pressures and their spatial patterns in European running waters. Water Environ. J. 2012, 26, 261-273. [CrossRef] 
80. Stranzl, S. Quantification of Human Impacts on Fish Assemblages in the Upper Volta Catchment, Burkina Faso. Master's Thesis, University of Natural Resources and Life Sciences (BOKU), Vienna, Austria, 2014.

81. Melcher, A.; Ouédraogo, R.; Moog, O.; Slezak, G.; Savadogo, M.; Sendzimir, J. Healthy fisheries sustain society and ecology in Burkina Faso. In Riverine Ecosystem Management; Schmutz, S., Sendzimir, J., Eds.; Springer: Cham, Switzerland, 2018; pp. 519-539.

82. MRAH. Stratégie Nationale De Développement Durable De La Pêche Et De l'Aquaculture à L'Horizon 2025; Ministère des Ressources Animales et Halieutiques: Ouagadougou, Burkina Faso, 2013; p. 35.

83. FAO. Code of Conduct for Responsible Fisheries; FAO: Rome, Italy, 2019.

84. SUSFISH Consortium. Sustainable Management of Water and Fish Resources in Burkina Faso-a Synthetic Overview of the SUSFISH Project. Supported by the Austrian Partnership Programme in Higher Education $\mathcal{E}$ Research for Development; Final report; SUSFISH-Plus: Ouagadougou, Burkina Faso; Vienna, Austria, 2015; Available online: http://susfish.boku.ac.at/download.htm (accessed on 1 April 2019).

85. Sendzimir, J. Synthesis: Conceptual modelling. In SUSFISH Book: Sustainable Fisheries and Water Management Transformation Pathways for Burkina Faso, 1st ed.; Melcher, A.H., Ouedraogo, R., Oueda, A., Sendzimir, J., Slezak, G., Somda, J., Toé, P., Voigt, C., Eds.; SUSFISH-Plus: Ouagadougou, Burkina Faso; Vienna, Austria, 2020; in press.

86. Andrachuk, M.; Armitage, D. Understanding social-ecological change and transformation through community perceptions of system identity. Ecol. Soc. 2015, 20, 26. [CrossRef]

87. Ouedraogo, R.; Soara, A.E.; Oueda, A. Description du peuplement piscicole du lac sahélien de Higa, un site Ramsar du Burkina Faso, Afrique de l'Ouest. J. Appl. Biosci. 2015, 95, 8958-8965. [CrossRef]

88. Rösslberg, G. Back to Basics: Traditional Inland Fisheries Management and Enhancement Systems in Sub-Saharan Africa and Their Potential for Development; Deutsche Gesellschaftfür Technische Zusammenarbeit (GTZ) GmbH Eschborn: Eschborn, Germany, 2002.

89. Blaikie, P.; Brown, K.; Stocking, M.; Tang, L.; Dixon, P.; Sillitoe, P. Knowledge in action: Local knowledge as a development resource and barriers to its incorporation in natural resource research and development. Agric. Syst. 1997, 55, 217-237. [CrossRef]

90. Krupnik, I.; Jolly, D. The Earth Is Faster Now: Indigenous Observations of Arctic Environmental Change; Krupnik, I., Jolly, D., Eds.; Arctic Research Consortium of the United States: Fairbanks, AL, USA, 2002; ISBN 0-9720449-0-6.

91. Berkes, F.; Colding, J.; Folke, C. Rediscovery of traditional ecological knowledge as adaptive management. Ecol. Appl. 2000, 10, 1251-1262. [CrossRef]

92. Drew, J.A. Use of traditional ecological knowledge in marine conservation. Conserv. Biol. 2005, 19, 1286-1293. [CrossRef]

93. Fraser, D.J.; Coon, T.; Prince, M.R.; Dion, R.; Bernatchez, L. Integrating traditional and evolutionary knowledge in biodiversity conservation: A population level case study. Ecol. Soc. 2006, 11, 4. [CrossRef]

94. Sachs, J.; Warner, A.M. Sources of slow growth in African economies. J. Afr. Econ. 1997, 6, 335-376. [CrossRef]

95. Gilchrist, G.; Mallory, M.; Merkel, F. Can local ecological knowledge contribute to wildlife management? Case studies of migratory birds. Ecol. Soc. 2005, 10, 20. [CrossRef]

96. Ruddle, K.; Davis, A. What is "ecological" in local ecological knowledge? Lessons from Canada and Vietnam. Soc. Nat. Resour. 2011, 24, 887-901. [CrossRef]

97. Boonstra, W.; Nhung, P.H.T. The ghosts of fisheries management. J. Nat. Resour. Policy Res. 2011, 4, 1-25. [CrossRef]

98. Pokorny, B.; von Lübke, C.; Dayamba, S.D.; Dickow, H. All the gold for nothing? Impacts of mining on rural livelihoods in Northern Burkina Faso. World Dev. 2019, 119, 23-39. [CrossRef]

99. Bazillier, R.; Girard, V. The gold digger and the machine. Evidence on the distributive effect of the artisanal and industrial gold rushes in Burkina Faso. J. Dev. Econ. 2020, 143, 102411. [CrossRef]

100. Luxereau, A.; Genthon, P.; Karimou, J.M.A. Fluctuations in the size of Lake Chad: Consequences on the livelihoods of the riverain peoples in eastern Niger. Reg. Environ. Chang. 2012, 12, 507-521. [CrossRef]

101. Harrod, C. Climate change and freshwater fisheries. In Freshwater Fisheries Ecology; Craig, J.F., Ed.; John Wiley \& Sons, Ltd.: Oxford, UK, 2015; pp. 641-694.

102. van de Giesen, N.; Liebe, J.; Jung, G. Adapting to climate change in the Volta Basin, West Africa. Curr. Sci. 2010, 98, 1033-1037.

103. Lebel, T.; Diedhiou, A.; Laurent, H. Seasonal cycle and interannual variability of the Sahelian rainfall at hydrological scales. J. Geophys. Res. D Atmos. 2003, 108, 1-11. [CrossRef] 
104. IPCC. Climate Change 2007: Contribution of Working Groups I, II and III to the Fourth Assessment Report of the Intergovernmental Panel on Climate Change; The Core Writing Team, Pachauri, R.K., Reisinger, A., Eds.; IPCC: Geneva, Switzerland, 2007; ISBN 9291691224.

105. Bates, B.; Kundzewicz, Z.W.; Wu, S.; Palutikof, J. Climate Change and Water. Technical Paper of the Intergovernmental Panel on Climate Change; IPCC Secretariat: Geneva, Switzerland, 2008.

106. Paugy, D.; Lévêque, C.; Duponchelle, F. Life-history strategies. In The Inland Water Fishes of Africa: Diversity, Ecology and Human Use; Paugy, D., Lévêque, C., Otero, O., Eds.; IRD Éditions: Marseille, France, 2017; pp. 178-188.

107. Darwall, W.; Smith, K.; Allen, D.; Holland, R.; Harrison, I.; Brooks, E. The Diversity of Life in African Freshwaters: Underwater, Under Threat: An Analysis of the Status and Distribution of Freshwater Species throughout Mainland Africa; IUCN: Gland, Switzerland, 2011; ISBN 978-2-8317-1345-8.

108. Ouedraogo, R.; Soara, A.E.; Zerbo, H. Caractérisation du peuplement piscicole du réservoir de Boalin, Ziniaré (Burkina Faso) deux décennies après l'introduction de Heterotis niloticus. Int. J. Biol. Chem. Sci. 2015, 9, 2488-2499. [CrossRef]

109. Béné, C. Diagnostic Study of the Volta Basin Fisheries: Part 1-Overview of the Fisheries Resources; WorldFish Center Regional Offices for Africa and West Asia, Cairo Egypt, and CPWF: Colombo, Sri Lanka, 2007.

110. Béné, C.; Russell, A.J.M. Diagnostic Study of the Volta Basin Fisheries: Part 2-Livelihoods and Poverty Analysis, Current Trends and Projections; WorldFish Center Regional Offices for Africa and West Asia, Cairo, Egypt, and CPWF: Colombo, Sri Lanka, 2007.

111. Vye, S.R.; Emmerson, M.C.; Arenas, F.; Dick, J.T.A.; O'Connor, N.E. Stressor intensity determines antagonistic interactions between species invasion and multiple stressor effects on ecosystem functioning. Oikos 2015, 124, 1005-1012. [CrossRef]

112. Vinebrooke, R.D.; Kathryn, L.C.; Jon, N.; Marten, S.; Stanley, I.D.; Stephen, C.M.; Ulrich, S. Impacts of multiple stressors on biodiversity and ecosystem functioning: The role of species co-tolerance. Oikos 2004, 104, 451-457. [CrossRef]

113. Schinegger, R.; Palt, M.; Segurado, P.; Schmutz, S. Untangling the effects of multiple human stressors and their impacts on fish assemblages in European running waters. Sci. Total Environ. 2016, 573, 1079-1088. [CrossRef]

114. Nõges, P.; Argillier, C.; Borja, Á.; Garmendia, J.M.; Hanganu, J.; Kodeš, V.; Pletterbauer, F.; Sagouis, A.; Birk, S. Quantified biotic and abiotic responses to multiple stress in freshwater, marine and ground waters. Sci. Total Environ. 2016, 540, 43-52. [CrossRef]

115. Folt, C.L.; Chen, C.Y.; Moore, M.V. Synergism and antagonism among multiple stressors. Limnol. Oceanogr. 1999, 44, 864-877. [CrossRef]

116. Côté, I.M.; Darling, E.S.; Brown, C.J. Interactions among ecosystem stressors and their importance in conservation. Proc. R. Soc. B Biol. Sci. 2016, 283, 20152592. [CrossRef]

117. Przeslawski, R.; Byrne, M.; Mellin, C. A review and meta-analysis of the effects of multiple abiotic stressors on marine embryos and larvae. Glob. Chang. Biol. 2015, 21, 2122-2140. [CrossRef]

118. Harvey, B.P.; Gwynn-Jones, D.; Moore, P.J. Meta-analysis reveals complex marine biological responses to the interactive effects of ocean acidification and warming. Ecol. Evol. 2013, 3, 1016-1030. [CrossRef]

119. Vannevel, R. Using DPSIR and balances to support water governance. Water 2018, 10, 118. [CrossRef]

120. Patrício, J.; Elliott, M.; Mazik, K.; Papadopoulou, K.-N.; Smith, C.J. DPSIR-Two decades of trying to develop a unifying framework for marine environmental management? Front. Mar. Sci. 2016, 3, 177. [CrossRef]

121. Daniels, P.L. Climate change, economics and Buddhism-Part I: An integrated environmental analysis framework. Ecol. Econ. 2010, 69, 952-961. [CrossRef]

122. Nguyen, T.H.T.; Everaert, G.; Boets, P.; Forio, M.A.E.; Bennetsen, E.; Volk, M.; Hoang, T.H.T.; Goethals, P.L.M. Modelling tools to analyze and assess the ecological impact of hydropower dams. Water 2018, 10, 259. [CrossRef]

123. Melcher, A. Annual Report of the SUSFISH-Plus Project; University of Natural Resources and Life Sciences: Vienna, Austria, 2019.

124. Zan, L.M. Politiques de population et de réduction de la fécondité au Burkina Faso: Limites et perspectives. Afr. Popul. Stud. 2016, 30. [CrossRef]

125. Ministère de la Santé Plan. National D'Accélération De Planification Familiale Du Burkina Faso 2017-2020; Ministère de la Santé: Ouagadougou, Burkina Faso, 2017. 
126. Anoh, A.; Fassassi, R.; Vimard, P. Politique de population et Planification Familiale en Côte d'Ivoire. In Les Politiques De Planification Familiale: Cinq Expériences Nationales; Gautier, A., Ed.; CEPED: Nogent-sur-Marne, France, 2004; pp. 195-231.

127. Breierova, L.; Duflo, E. The Impact of Education on Fertility and Child Mortality: Do Fathers Really Matter Less Than Mothers? Nber Working Paper Series; National Bureau of Economic Research: Cambridge, MA, USA, 2004.

128. Canning, D.; Raja, S.; Yazbeck, A.S. Africa's Demographic Transition: Dividend or Disaster? Africa Development Forum series; The World Bank: Washington, DC, USA, 2015; ISBN 978-1-4648-0490-8.

129. Toé, P. Pêche, environnement et société: Contribution des sciences sociales sur les pêcheries traditionnelles en pays Bisa (Burkina Faso). Cah. du Cent. d'études Rech. en lettres Sci. Hum. Soc. 1999, 16, 301-318.

130. Toé, P.; Sanon, V.-P. Gouvernance Et Institutions Traditionnelles Dans Les Pêcheries De l'Ouest Du Burkina Faso; L'Harmattan: Paris, France, 2015; ISBN 978-2-343-04967-0.

131. Buur, L.; Kyed, H.M. State Recognition and Democratization in Sub-Saharan Africa; Palgrave Macmillan: New York, NY, USA, 2007; ISBN 978-0-230-60971-6.

132. Froehlich, H.E.; Gentry, R.R.; Halpern, B.S. Conservation aquaculture: Shifting the narrative and paradigm of aquaculture's role in resource management. Biol. Conserv. 2017, 215, 162-168. [CrossRef]

133. De Graaf, G. Sustainable Fisheries Management and Culture-Based Fisheries in Reservoirs a Case Study from Burkina Faso. 2003. Available online: http://citeseerx.ist.psu.edu/viewdoc/download?doi=10.1.1.534. 6168\&rep=rep1\&type $=$ pdf (accessed on 1 April 2019).

134. Allison, E.H.; Ellis, F. The livelihoods approach and management of small-scale fisheries. Mar. Policy 2001, 25, 377-388. [CrossRef]

135. Kaboré, I.; Moog, O.; Ouéda, A.; Sendzimir, J.; Ouedraogo, R.; Guenda, W.; Melcher, A.H. Developing reference criteria for the ecological status of West African rivers. Environ. Monit. Assess. 2018, 190, 2. [CrossRef]

136. Zerbo, H.; Ouattara, D.; Soubeiga, Z.; Kabore, K.; Kabore, C.; Bado, E.; Goumbri, B.A.; Yerbanga, R.A.; Ouedraogo, N.; Baro, S. Analyse De La Filière Pêche Au Burkina Faso. Projet d'Appui Au Renforcement des Capacités d'Analyse Des Impacts Des Politiques Agricoles; Direction Générale des Ressources Halieutiques. Ministère de l'Agriculture, de l'Hydraulique et des Ressources Halieutiques: Ouagadougou, Burkina Faso, 2007.

137. Miller, J. The potential for development of aquaculture and its integration with irrigation within the context of the FAO special programme for food security in the Sahel. In Integrated Irrigation and Aquaculture in West Africa: Concepts, Practices and Potential; Halwart, M., Dam, A.A., Eds.; Food and Agriculture Organization of the United Nations: Rome, Italy, 2006.

138. Obiero, K.; Meulenbroek, P.; Drexler, S.; Dagne, A.; Akoll, P.; Odong, R.; Kaunda-Arara, B.; Waidbacher, H. The contribution of fish to food and nutrition security in Eastern Africa: Emerging trends and future outlooks. Sustainability 2019, 11, 1636. [CrossRef]

139. Iwama, G.K. Interactions between aquaculture and the environment. Crit. Rev. Environ. Control 1991, 21, 177-216. [CrossRef]

140. George, A.L.; Kuhajda, B.R.; Williams, J.D.; Cantrell, M.A.; Rakes, P.L.; Shute, J.R. Guidelines for propagation and translocation for freshwater fish conservation. Fisheries 2009, 34, 529-545. [CrossRef]

141. Fraser, D.J. How well can captive breeding programs conserve biodiversity? A review of salmonids. Evol. Appl. 2008, 1, 535-586. [CrossRef] [PubMed]

(C) 2020 by the authors. Licensee MDPI, Basel, Switzerland. This article is an open access article distributed under the terms and conditions of the Creative Commons Attribution (CC BY) license (http://creativecommons.org/licenses/by/4.0/). 